\title{
AS APOCYNACEAE $S$. STR. DA REGIÃO DE BAURU, SÃO PAULO, BRASIL ${ }^{1}$
}

\author{
Ingrid Koch ${ }^{2}$ \\ Luiza Sumiko Kinoshita ${ }^{2}$
}

Recebido em 25/08/1998. Aceito em 30/03/1999

\begin{abstract}
RESUMO - (As Apocynaceae s. str: da região de Bauru, São Paulo. Brasil). Este trabalho consistiu no levantamento das Apocynaceae na Região de Bauru, centro-oeste do estado de São Paulo, em diferentes tipos de vegetação. Foram encontradas 25 espécies, distribuídas em 15 gêneros, representadas nesta ordem: Forsteronia G. Mey., cinco espécies: Aspidosperma Mart., quatro espécies; Mandevilla Lindl., três espécies: Prestonia R. Br., duas espécies, e Condylocarpon Desf., Hancornia Gomez, Himatanthus Willd. ex Roem. et Schult.. Macrosiphonia Müll.Arg., Mesechites Müll.Arg., Odontadenia Benth., Peltastes Woodson, Rhodocalıx Müll.Arg.. Secondatia A. DC., Tabernaemontana L. e Temnadenia Miers. uma espécie cada. São apresentadas chaves de identificação, descrições e ilustrações das espécies, além de dados de distribuição geográfica, floração e frutificação.
\end{abstract}

Palavras-chave - florística, Apocynaceae, Bauru, São Paulo, Brasil

\begin{abstract}
The Apocynaceae s, str: of the Bauru region, São Paulo State, Brazil). The present study describes a survey of the Apocynaceae in different types of vegetation. in the region of Bauru, in the Center-West of São Paulo State. Of the 25 species encountered, distributed into 15 genera. representation ranges as follows: Forsteronia G. Mey, five species: Aspidosperma Mart., four species; Mandevilla Lindl., three species; Prestonia R. Br., two species: and Condylocarpon Desf., Hancornia Gomez, Himatanthus Willd. ex Roem. et Schult., Macrosiphonia Müll. Arg,, Mesechites Muill. Arg., Odontadenia Benth, Peltastes Woodson, Rhodocaly: Müll Arg., Secondatia A. DC., Tabemaemontana L. and Temnadenia Miers, one species each. In addition to both distribution data, and flowering and fruiting times, identifications keys, descriptions and illustrations of the species are presented.
\end{abstract}

Key words - floristic, Apocynaceae. Bauru, São Paulo. Brazil

\section{Introdução}

A família Apocynaceae apresenta cerca de 300 gêneros e 2.000 espécies distribuídos nas regiões tropicais e subtropicais do mundo (Barroso et al. 1986). Allorge (1980) citou 52 gêneros e 377 espécies para a América do Sul, sendo 26 gêneros considerados endêmicos para o continente. São estimados 41 gêneros e 376 espécies para o Brasil (Barroso et al. 1986).

A família é bastante interessante do ponto de vista fitoquímico e sistemático. Seus representantes têm se destacado pela utilidade econômica, quer seja em termos de fornecimento

\footnotetext{
Parte da Dissertação de Mestrado do primeiro autor

Departamento de Botânica, UNICAMP. C. Postal 6109, CEP 13081-970. Campinas, SP, Brasil
} 
de látex, glicosídeos cardiotônicos, alcalóides, antibióticos e madeiras, como também por suas plantas ornamentais (Rizzini \& Mors 1976). Além disso, a morfologia complexa dos orgãos reprodutivos reflete vários estádios evolutivos que culminariam nas Asclepiadaceae, fato que tem motivado vários autores a reavaliar a circunscrição desta família, utilizando inclusive dados macromoleculares (Judd et al. 1994; Struwe et al. 1994; Sennblad \& Bremer 1996).

Estudos da família foram realizados nas Américas por Miers (1878), Woodson (1930, 1933, 1935b, 1936) e Allorge (1983) e no Brasil por Müller (1860), Azambuja (1947) e Markgraf (1968). Poucos levantamentos têm sido realizados para floras locais, podendo-se citar o da Reserva do Parque Estadual das Fontes do Ipiranga, São Paulo (Kinoshita-Gouvêa \& Baldassari 1987) e o de Poços de Caldas, Minas Gerais (Bragatto-Vasconcelos \& KinoshitaGouvêa 1993). Além desses, tem-se o "checklist" das Apocynaceae da Ilha do Cardoso (Sugiyama 1991).

A região de Bauru é bastante interessante para estudos botânicos por possuir grande variedade de formações vegetais, algumas delas protegidas por lei. A vegetação é constituída por formações de mata, cerradões, cerrados, além de áreas de capoeira e várzeas, que correspondem a $3,44 \%$ da vegetação nativa total do estado (Kronka et al. 1993). Nos levantamentos florísticos e fitossociológicos com espécies arbóreas, realizados na região (Ferracini et al. 1983; Cavassan et al. 1984; Cavassan 1990), a família Apocynaceae mostrou-se representativa. Esta região é uma das que sofreu os maiores índices de redução da cobertura vegetal natural, $51,4 \%$ registrados entre 1962 e 1992, com a taxa mais drástica ocorrendo nas categorias de cerradão, cerrado e campo cerrado, que foi de $70,43 \%$ entre 1971 e 1992 (Kronka et al. 1993).

O objetivo deste trabalho foi o de inventariar as espécies da família Apocynaceae para a região de Bauru, avaliar a representatividade atual e fornecer subsídios para o reconhecimento das mesmas nos diversos tipos de vegetação.

\section{Material e métodos}

O município de Bauru localiza-se na porção centro-oeste do estado de São Paulo, nas coordenadas $22^{\circ} 19^{\prime} \mathrm{S}$ e $49^{\circ} 04^{\prime} \mathrm{W}$, a $609 \mathrm{~m}$ de altitude, limitando-se com os municípios de Reginópolis, Pirajuí, Avaí, Arealva, Pederneiras e Agudos (Fig. 1).

Os herbários BAUR, BOTU, ESA, R, RB, SP, SPF, SPSF, UEC, UNBA foram consultados a fim de se verificar coletas para a região e anotar dados de floração e frutificação. As siglas dos herbários visitados estão de acordo com Holmgren et al. (1990), com exceção de UNBA, ainda não indexado.

As coletas foram realizadas em áreas preferencialmente protegidas ao redor do município por um período de dois anos, a cada 20 dias, em caminhadas assistemáticas. As áreas de coleta (Fig. 1) incluíram a Estação Ecológica de Bauru, com vegetação do tipo floresta estacional mesófila semidecídua (Cavassan et al. 1984); o vale do Rio Batalha, com mata ciliar; o campus de Bauru da Universidade Estadual Paulista "Júlio de Mesquita Filho" (UNESP), com vegetação fisionomicamente do tipo cerradão (Coutinho 1978); o Jardim Botânico de Bauru, com formação de transição entre cerradão e mata estacional semidecídua e uma formação de mata de brejo; a Reserva Natural da Bacia do Ribeirão Pelintra, com formações de mata estacional semidecídua, mata tropical de solo encharcado e cerrado s. str. (Coutinho 1978).

Neste trabalho considerou-se a classificação de Cronquist (1981) para a circunscrição da família e a classificação de Leeuwenberg (1994a) para as subfamílias. O material coletado foi identificado, descrito e ilustrado da maneira convencional utilizada em taxonomia. São citados apenas os sinônimos mais recentes e encontrados freqüentemente nas exsicatas dos herbários. Em alguns casos, material de outras regiões também foi analisado para complementar informações não obtidas nas exsicatas da região, e está listado no item "material adicional examinado". Após a descrição de cada gênero, é citada a bibliografia utilizada para identificação das espécies e os dados 


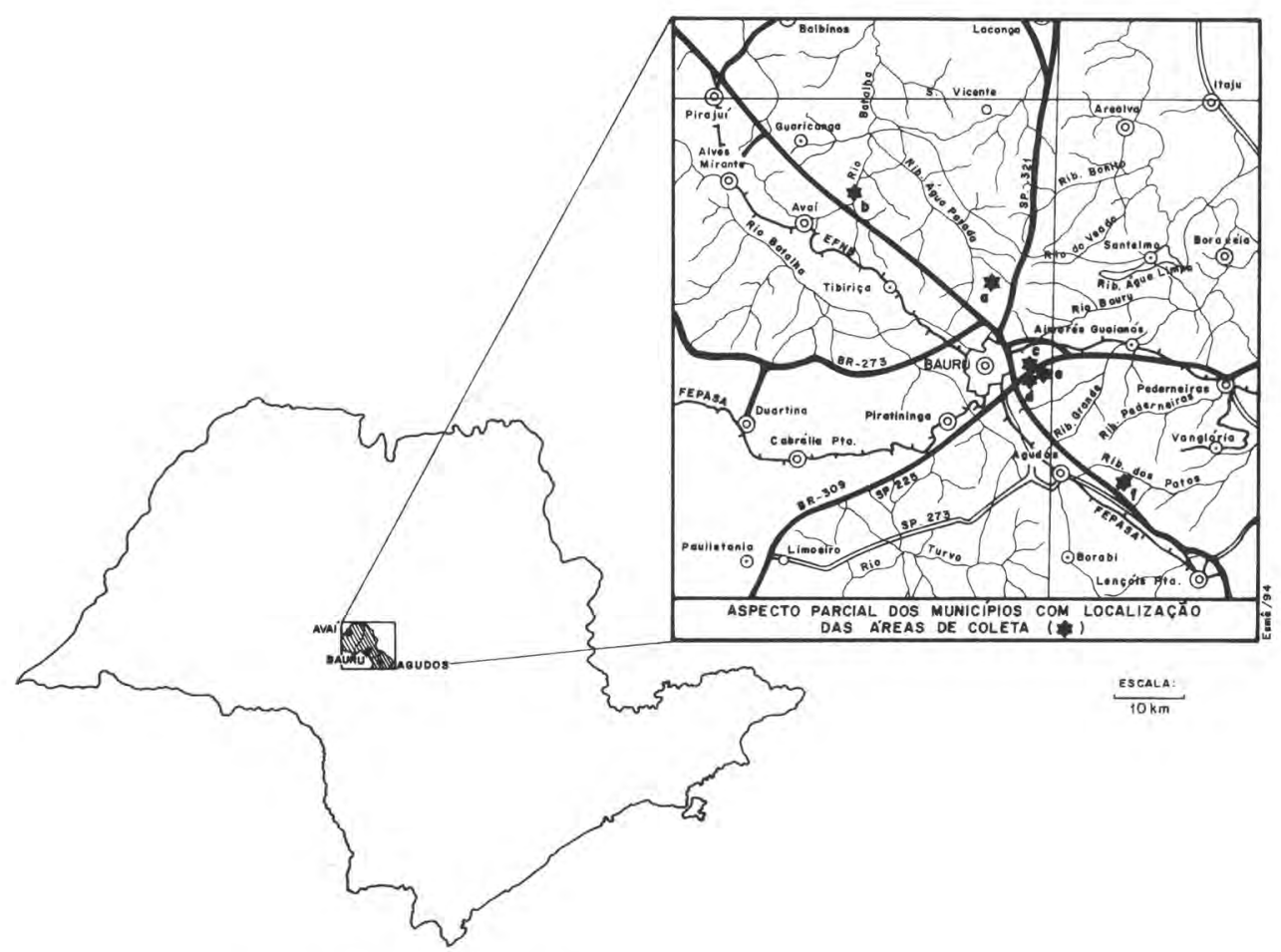

Figura 1. Localização dos municípios estudados no Estado de S. Paulo e áreas de coleta: a) Estação Ecológica de Bauru; b) vale do rio Batalha; c e d) campus da UNESP de Bauru; e) Jardim Botânico de Bauru; f) Cia. Cervejaria Brahma

de distribuição geográfica. Além dessas referências, foram utilizadas Barroso et al. (1986), Ettingshaussen (1861 apud Felippe \& Alencastro 1966), Lawrence (1951), Radford (1974) e Woodson (1935a) para identificação dos gêneros e descrição do material. Para os gêneros representados por apenas uma espécie é apresentada apenas a descrição da espécie, uma vez que foi baseada no material coletado na região, Os dados de floração e frutificação foram obtidos através de observações no campo, informações obtidas de etiquetas de materiais de herbário, preferencialmente do Estado de São Paulo, e bibliografia relacionada, quando não era possível obter tal informação nas fontes anteriores.

O material testemunho encontra-se depositado no herbário UEC, do Departamento de Botânica da Universidade Estadual de Campinas (UNICAMP), e as duplicatas foram doadas ao herbário UNBA do Departamento de Ciências Biológicas da UNESP de Bauru.

\section{Resultados e discussão}

Apocynaceae Juss.

Arbustos, subarbustos ou lianas latescentes, mais raramente árvores ou ervas. Folhas simples, opostas, alternas ou verticiladas, em geral sem estípulas. Inflorescências cimosas, racemosas ou por vezes, flores isoladas. Flores gamopétalas, actinomorfas ou pouco zigomorfas, 5-meras; corola tubulosa, infundibuliforme, rotácea ou hipocrateriforme; estames epipétalos com anteras justapostas à cabeça do estilete; ovário súpero (semi-ínfero em Himatanthus), 2-carpelar, apocárpico ou sincárpico, portando óvulos numerosos, em geral com disco nectarífero, inteiro, lobado, ou até 5 nectários livres. Fruto folicular ou bacáceo (raro).

Foram coletadas 25 espécies pertencentes a 15 gêneros e duas subfamílias. Os gêneros melhor representados foram Forsteronia (5 spp.) da subfamília Apocynoideae e Aspidosperma (4 spp.) 
da subfamília Plumerioideae. A subfamília Apocynoideae apresentou o maior número de espécies (17 spp.).

Chave para os gêneros de Apocynaceae da região de Bauru

1. Prefloração sinistrorsa (exceto em Himatanthus); anteras férteis até a base, livres da cabeça do estilete; sementes sem coma, aladas ou não (Plumerioideae)

2. Ovário sincárpico; fruto carnoso do tipo bacáceo 3. Hancornia

2. Ovário apocárpico; fruto seco do tipo folicular 3. Inflorescência articulada, brácteas foliáceas ca. $2 \mathrm{~cm}$ compr. .... 4. Himatanthus

3. Inflorescência não articulada, brácteas escariosas até $0,5 \mathrm{~cm}$ compr.

4. Folhas verticiladas, domácias em tufos de tricomas nas axilas das nervuras; lobos da corola caudados; frutos indeiscentes

2. Condylocarpon

4. Folhas opostas ou alternas, domácias ausentes; lobos da corola não caudados; frutos deiscentes

5. Coléteres no cálice das flores; folículos com sementes ariladas

\section{Tabernaemontana}

5. Coléteres ausentes no cálice das flores; folículos com sementes aladas

1. Aspidosperma

1. Prefloração dextrorsa, anteras parcialmente férteis e adnatas à cabeça do estilete; sementes comosas (Apocynoideae).

6. Base da antera obtusa ou truncada

7. Corola hipocrateriforme, inflorescência subcorimbosa 9. Mesechites

7. Corola infundibuliforme, inflorescência racemosa

8. Flores brancas, tubo 4 a 5 vezes maior que os lobos da corola

7. Macrosiphonia

8. Flores róseas, tubo até 3 vezes maior que os lobos da corola

8. Mandevilla

6. Base da antera sagitada, aguda ou caudada

9. Folhas peltadas

11. Peltastes

9. Folhas não peltadas
10. Corola rotácea a subrotácea, ca. $0,5 \mathrm{~cm}$ compr. .... 6. Forsteronia

10. Corola não rotácea, $1,5 \mathrm{~cm}$ compr. ou mais.

11. Coléteres opostos aos lacínios do cálice

12. Corola infundibuliforme

15. Temnadenia

12. Corola hipocrateriforme 13. Lianas; brácteas de coloração tênue, amarelada

\section{Prestonia}

13. Subarbustos; brácteas de coloração viva, vinácea

... 13. Rhodocalyx

11. Coléteres alternos aos lacínios do cálice

14. Estípulas interpeciolares; corola infundibuliforme, lacínios do cálice desiguais

..10. Odontadenia

14. Estípulas interpeciolares ausentes; corola hipocrateriforme, lacínios do cálice de tamanhos semelhantes

.... 14. Secondatia

\section{Subfamília Plumerioideae}

Prefloração sinistrorsa (exceto em Himatanthus); anteras férteis até a base, livres da cabeça do estilete; sementes sem coma, aladas ou não. É representada na região pelos gêneros: Aspidosperma, Condylocarpon, Hancornia, Himatanthus e Tabernaemontana.

\section{Aspidosperma Mart.}

Árvores; folhas alternas, desprovidas de coléteres, pecioladas ou sésseis. Inflorescência cimosa, em geral axilar e subterminal; brácteas escariosas, muitas vezes de difícil observação. Flores pequenas, alvo-amareladas ou amareladas; 
cálice sem coléteres; corola hipocrateriforme; estames inclusos no quarto superior do tubo, filetes curtos e delgados; anteras livres, glabras, pequenas, ovadas, ápice agudo e base cordiforme; ovário apocárpico; nectários ausentes; estilete filiforme; cabeça do estilete subcapitada com dois apêndices apicais. Folículos lenhosos, eretos, aplanados lateralmente a subcilíndricos; sementes aladas.

O gênero possui 43 espécies de distribuição neotropical, sendo que a maioria ocorre no Brasil.

Bibliografia utilizada: Woodson (1951); Marcondes-Ferreira (1988); Marcondes-Ferreira \& Kinoshita (1996).

Chave de identificação para as espécies de Aspidosperma

1. Caule e ramos corticosos; folhas denso-lanosas, sésseis 1.4. A. tomentosum

1. Caule e ramos não corticosos; folhas glabras, pecioladas ou subsésseis

2. Nervuras secundárias das folhas distantes ca. $1 \mathrm{~cm}$ uma da outra; inflorescência ramiflora, folículos dolabriformes ... 1.3. A. ramiflorum

2. Nervuras secundárias das folhas distantes ca. $2 \mathrm{~mm}$ uma da outra; inflorescência subterminal, folículos oblongos

3. Folhas elípticas a oblongo-ovadas; pecíolo de 2-3,8cm compr. ; folículos subcilíndricos 1.1. A. cylindrocarpon

3. Folhas lanceoladas a oblanceoladas; pecíolo de 0,5-1 cm compr.; folículos aplanados 1.2. A. polyneuron

\subsection{Aspidosperma cylindrocarpon Müll.}

Arg. in Mart., Fl. bras. 6(1): 54. 1860.

Fig. 2-4

Nome vulgar: peroba

Árvore de até $15 \mathrm{~m}$ alt.; caule suberoso, sulcado longitudinalmente. Folhas elípticas a oblongo-ovadas, ápice agudo a acuminado, base aguda, assimétrica ou obtusa, 6,5-13×3-7cm; membranáceas a subcoriáceas; concolores; glabras; venação broquidódroma, nervuras secundárias distanciadas ca. $2 \mathrm{~mm}$ umas das outras; pecíolo $2-3,8 \mathrm{~cm}$ compr. Inflorescência cimeira composta, laxa. Flores alvo-amareladas, 6-8mm compr.; lacínios do cálice ovais; lobos da corola lineares; ovário glabro. Folículos divergentes, eretos, castanho claros, lenticelados, oblongos, subcilíndricos, glabros, $6-8 \times 2-2,5 \mathrm{~cm}$; sementes oblongas, ala unilateral.

Ocorre no Peru, Bolívia, Brasil (Regiões Centro-Oeste, Sudeste e Sul) e Paraguai. Foi observada em mata estacional semidecídua, mata ciliar e em região de transição entre mata e cerradão. Flores de setembro a novembro e frutos de fevereiro a setembro.

Esta espécie se caracteriza pelos frutos subcilíndricos e folhas com pecíolos longos.

Material examinado: BRASIL. São Paulo: Agudos, X/1992, fl., Cavassan et al. 30775 (UEC); Avaí, IV/1992, fr., Koch 17 et al. (UEC); Bauru, II/1991, fr., Itomar 18 (SPSF); Bauru, VIII/ 1993, fr., Koch 132 et al. (UEC); Bauru, IX/1993, f1., Koch 143 \& Azevedo (UEC).

Material adicional examinado: BRASIL. São Paulo: Jaú, IX/1988, fl., Nicolini s/n (ESA 5947).

1.2. Aspidosperma polyneuron Müll. Arg. in Mart., Fl. bras. 6(1): 1860.

Fig. 5-7

Nomes vulgares: peroba, peroba-rosa

Árvore ca. $30 \mathrm{~m}$ alt.; caule suberoso, fissurado. Folhas lanceoladas a oblanceoladas, ápice agudo a arredondado, base aguda; 7 11,5×2,3-4cm; cartáceas; concolores; venação reticulódroma; pecíolo $0,5-1 \mathrm{~cm}$ compr. Inflorescência cimeira composta, congesta. Flores amareladas, ca. $5 \mathrm{~mm}$ compr.; lacínios do cálice ovados; lobos da corola lanceolados; ovário piloso na metade superior. Folículos divergentes, castanhos, lenticelados, oblongos, aplanados, mucronados, 3,2-5x 1-1,5cm; sementes aladas, ala unilateral.

Ocorre na América do Sul, principalmente na Colômbia e no Brasil. É bastante abundante nas matas da região. Floresce de novembro a janeiro e foram observados frutos durante quase todo o ano. É uma árvore de grande porte. reconhecida por seu tronco fissurado e nervação reticulada de suas folhas. 


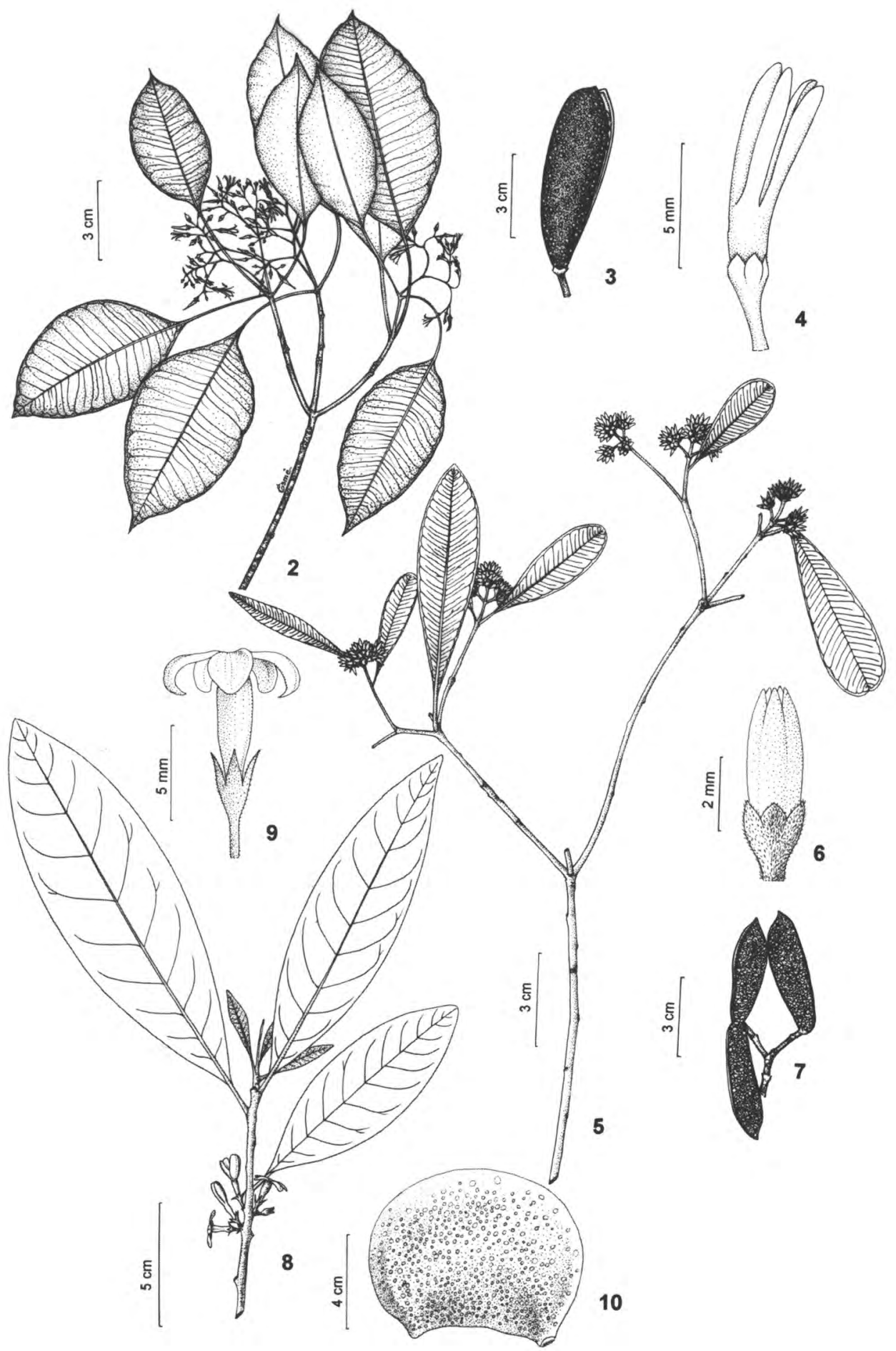

Figuras 2-4. Aspidosperma cylindrocarpon Müll. Arg. :2. ramo com flores; 3. fruto (Koch 132 et al.); 4. flor (Koch 143 \& Azevedo). Fig. 5-7: A. polyneuron Müll.Arg.: 5. ramo com flores (Paulo s/n UEC 95438); 6. flor ( Tamashiro et al. 18.845); 7. fruto (Koch 118 \& Cavassan ). Fig. 8-10. A. ramiflorum Müll. Arg.: 8. ramo com flores; 9. flor ( Zandoval 36); 10. fruto (Grassi s/n UEC 95437). 
Material examinado: BRASIL. São Paulo: Bauru, VI/1993, fr., Koch 118 \& Cavassan (UEC); Bauru, X/1993, fr., Koch 155 \& Jesus (UEC).

Material adicional examinado: BRASIL. São Paulo: Piracicaba, X/1992, fl., Paulo s/n (UEC 95438); Teodoro Sampaio, XII/1986, fl., Tanashiro et al. 18.845 (SP, UEC).

1.3. Aspidosperma ramiflorum Müll. Arg. in Mart., Fl. bras. 6(1):55. 1860.

Fig. 8-10

Nome vulgar: guatambu

Árvores ca. 10m alt.; ramos lenticelados. Folhas elípticas, oblongo-elípticas a obovadas, ápice agudo, base aguda; 10,3-15,8×3,2-5,9cm; cartáceas; concolores; venação camptódroma, mais evidente na face abaxial, nervuras secundárias distantes ca. $1 \mathrm{~cm}$ umas das outras; pecíolo ca. $1 \mathrm{~cm}$. Inflorescência ramiflora, fasciculada, séssil, pauciflora. Flores amareladas, 1,5-1,7cm compr.; lacínios do cálice lanceolados; lobos da corola oblongos; ovário glabro. Folículos divergentes, castanhos, lenticelados, dolabriformes, aplanados, $8,5 \times 6 \mathrm{~cm}$; sementes aladas, ovais, quase concêntricas.

Ocorte nas regiões Sudeste e Sul do Brasil e na Bolívia. Foi encontrada em mata estacional semidecídua. Flores em setembro e frutos em julho.

Esta espécie caracteriza-se pela inflorescência ramiflora e por possuir flores e frutos maiores que os das demais espécies.

Material examinado: BRASIL. São Paulo: Bauru, V/1994, veg., Koch 189 et al. (UEC).

Material adicional examinado: BRASIL. São Paulo: Campinas, IX/1988, fl., Leitão Filho \& Morellato 20.753 (UEC); Piracicaba, IX/1985, fl., Zandoval 36 (ESA, UEC); Piracicaba, VII/ 1987, fr. Grassi s/n (UEC 95437).

\subsection{Aspidosperma tomentosum Mart,}

Flora 7(1) Beil. (4): 135. 1824.

Fig. 11-13

Nomes vulgares: guatambu, guatambu-docerrado, peroba

Árvore ca. $8 \mathrm{~m}$ alt.; caule suberoso. Folhas sésseis; oblanceoladas, ápice arredondado a agudo, base atenuada; 8,5-22,2×3-9,8cm; cartáceas; discolores; pilosas a lanosas, tricomas simples; venação craspedódroma. Inflorescência subterminal, corimbiforme; flores alvo-amareladas, 3$7 \mathrm{~mm}$ compr.; lacínios do cálice lanceolados a ovais; lobos da corola lineares; ovário glabro. Folículos divergentes, castanhos, denso-lanosos, piriformes, aplanados, mucronados, $6-7,4 \times 3,4-4,5 \mathrm{~cm}$; sementes aladas, ovais, concêntricas.

Ocorre na Venezuela, Brasil, Bolívia e Paraguai, em cerrados. Flores de setembro a dezembro e frutos em setembro e outubro.

O tronco desta pequena árvore é muito suberoso e contorcido, sendo planta típica dos cerrados da região. É espécie muito polimórfica, principalmente no que diz respeito ao tamanho e indumento de suas folhas.

Material examinado: BRASIL. São Paulo: Agudos, X/1994, Bertoncini \& Sena 411 (UNBA); Bauru, X/1992, fl., Koch 55 \& Cavassan (UEC); Bauru, X/1993, fr., Koch 157 \& Cavassan (UEC); Bauru, IX/1985, fl., Cavassan 342 (BAUR, HRCB); Lençois Paulista, VI/1995, fr., Tamashiro llll et al. (HRCB, SP, UEC).

\section{Condylocarpon Desf.}

Gênero neotropical com sete espécies, representado na região por $C$. isthmicum.

Bibliografia utilizada: Fallen (1983)

2.1. Condylocarpon isthmicum (Vell.) A. DC. in DC., Prodr. 8: 381.1844.

Echites isthnica Vell., Fl. Flum. 3: 112. 1929.

Condylocarpon rauwolfiae (A.DC.) Müll.

Arg. in Mart., Fl. Bras. 6(1):64. 1860.

Fig. 14-17

Liana; caule lenticelado; ramos opostos. Folhas verticiladas; elípticas, ovado-elípticas e oblongo-elípticas; ápice agudo a obtuso, base aguda a obtusa; 4,7-9,3×2,1-4,2cm; cartáceas a subcoriáceas; concolores; domácias em tufos de tricomas nas axilas das nervuras; venação broquidódroma, pecíolo ca. $1 \mathrm{~cm}$ compr. Inflorescência terminal, tirso com muitas flores, brácteas escariosas. Flores alvo-amareladas, 3$4 \mathrm{~mm}$ compr.; botões globosos; lacínios do cálice ovados; corola hipocrateriforme, lobos caudados, 


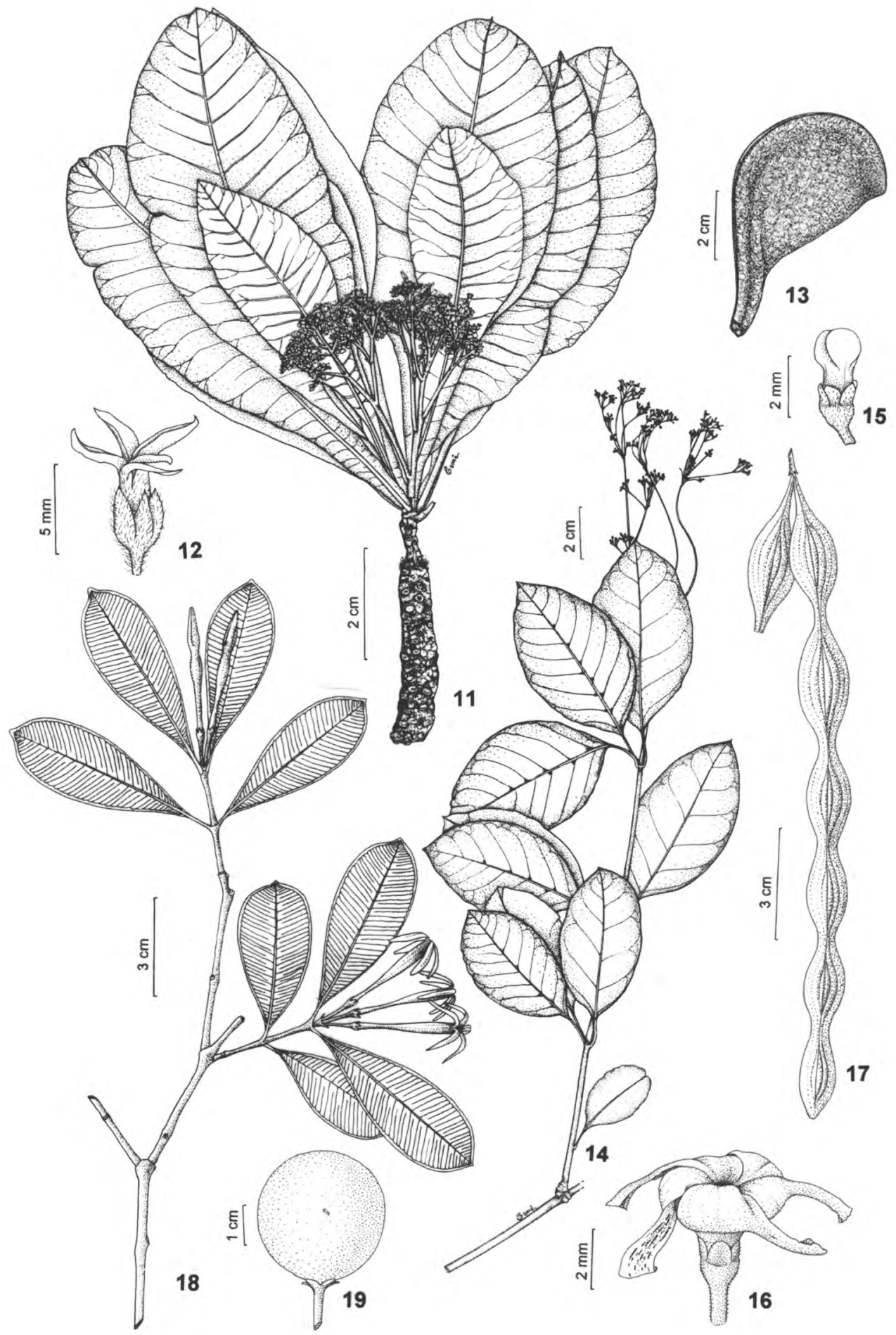

Figuras 11-13. Aspidosperma tomentosum Mart.: 11. ramo com flores; 12. flor 13. fruto (Koch 157 \& Cavassan ); Fig. $14-17$. Condylocarpon isthmicum (Vell.) A. DC.: 14. ramo com flores; 15. botão floral; 16. flor (Cavassan \& Koch 149); 17. fruto (Godoi \& Romaniuc Neto 193). Fig. 18-19. Hancornia speciosa Gomez. 18. ramo com flores; 19. fruto (Marcondes Ferreira et al. 1486). 
com manchas castanho-avermelhadas; estames na porção mediana do tubo, anteras livres; ovário apocárpico; cabeça do estilete subglobosa, subséssil. Folículos indeiscentes, pendentes, glabros, articulados, $10-17 \mathrm{~cm}$ compr., segmentos ca. $4 \mathrm{~cm}$, com uma semente cada; sementes fusiformes, verrucosas.

Esta espécie ocorre em matas e em campos do planalto Brasileiro, do Ceará a Argentina e Paraguai. Foi encontrada em mata ciliar e mata estacional semidecídua na região, florescendo de outubro a novembro e frutificando de janeiro a maio.

Caracteriza-se pelas folhas verticiladas e pelos frutos articulados, indeiscentes, com provável adaptação à hidrocoria (Fallen 1983).

Material examinado: BRASIL. São Paulo: Avaí, X/1993, fl., Cavassan \& Koch 149 (UEC); Bauru, I/1993, fr., Koch 86 \& Cavassan (UEC); Bauru, I/1993, fr., Cavassan 30.782 (UEC).

Material adicional examinado: BRASIL. São Paulo: Mogi Guaçu, IV/1992, fr., Godoi \& Romaniuc Neto 193 (UEC, SP).

\section{Hancornia Gomez}

Gênero monotípico distribuído por todo o Brasil e ao norte do Paraguai, principalmente em ambientes de cerrado.

Bibliografia utilizada: Monachino (1945)

\subsection{Hancornia speciosa Gomez in DC.,} Prodr. 8: 325. 1844.

Fig. 18-19

Nome vulgar: mangaba

Árvore ca. $5 \mathrm{~m}$ alt, caule rugoso, avermelhado; ramos angulosos, casca esfoliante. Folhas opostas; oblanceoladas a obovadas, ápice agudo a cuspidado, base aguda; 4,8-10,2×2,1$4.5 \mathrm{~cm}$; cartáceas; concolores; glabras; venação craspedódroma, nervuras secundárias paralelas entre si, pouco distanciadas; pecíolo 3-6 $\mathrm{mm}$ compr:; coléteres inconspícuos na região de inserção do pecíolo ao caule. Inflorescência terminal, cimosa, 3-5 flores; brácteas linearlanceoladas. Flores alvas, $3-3,5 \mathrm{~cm}$ compr.; lacínios do cálice ovados; corola hipocrateriforme, tubo cilíndrico, dilatado na região de inserção dos estames, duas a três vezes o tamanho dos lobos; lobos lineares; estames no terço superior do tubo; anteras livres, ápice apiculado e base cordiforme; ovário sincárpico, unilocular, glabro; cabeça do estilete fusiforme, com dois apêndices apicais. Baga ovóide a orbicular, $1-4 \mathrm{~cm}$ diâm.

Flores em novembro, frutos de novembro a março.

Material examinado: BRASIL. São Paulo: Agudos, V/1993 veg., Cavassan et al. 31.777 (UEC).

Material adicional examinado: BRASIL. São Paulo: Botucatu, III/1986, fr., Bicudo et al. 758 (BOTU, SP, UEC); Botucatu, XI/1986, fl., Bicudo \& Campos 1653 (BOTU, SP, UEC); Estreito, XI/1997, fl., fr., Marcondes Ferreira et al. 1486 (SP, UEC).

4. Himatanthus Willd. ex Roem. et Schult.

Gênero neotropical com 13 espécies. Bibliografia utilizada: Plumel (1991)

4.1. Himatanthus obovatus (Müll.Arg.) Woodson, Ann. Missouri Bot. Gard. 25: 201. 1937. Plumeria obovata Müll. Arg. in Mart., Fl. bras. $6(1): 40.1860$.

Fig. 20-23

Arbusto ca. $1,80 \mathrm{~m}$ alt.; caule suberoso. Folhas alternas, congestas no ápice dos ramos; obovadas, ápice obtuso a emarginado, base atenuada, margem inteira; 9,5-18 $\times 5-11,8 \mathrm{~cm}$; coriáceas; concolores; glabras; venação broquidódroma; pecíolo 3-7mm compr. Inflorescência terminal, articulada, mais longa que as folhas subtendidas; cincino dicotômico com eixo reduzido; brácteas subpetalóides, esverdeadas, ovais, ca. $2 \mathrm{~cm}$ compr.; coléteres na base, internamente. Flores alvas, 3,5-5cm compr.; lacínios do cálice desiguais, ovais; corola hipocrateriforme; tubo internamente amarelo; lobos oblongo-espatulados, maiores que o tubo; estames inseridos na porção basal do tubo, anteras livres; ovário apocárpico, semi-ínfero, glabro; cabeça do estilete cilíndrica, com dois apêndices no ápice e uma dobra na base. Folículos divergentes, reflexos, lenhosos, castanho-escuros, 
extremidades acuminadas e aplanadas, ca. $10 \mathrm{~cm}$ compr.; sementes aladas, circulares, concêntricas.

Himatanthus obovatus ocorre na Bolívia e no Brasil, onde é amplamente distribuída, principalmente em ambientes de campo e cerrado. O período de floração é de dezembro a março e a frutificação de maio a julho.

Material examinado: BRASIL. São Paulo: Bauru, VII/1992, fr., Koch 35 (UEC); Bauru, V/ 1993, fr., Koch 113 \& Azevedo (UEC); Bauru, II/ 1994, fl., Koch 177 (UEC).

\section{Tabernaemontana L.}

Gênero com ca. 110 espécies, de distribuição pantropical.

Bibliografia utilizada: Allorge (1983); Leeuwenberg (1994b).

\subsection{Tabernaemontana catharinensis A.}

DC. in DC., Prodr. 8: 365. 1844.

Fig. 24-26

Peschiera catharinensis (A. DC.) Miers, Apocyn. S. Amer.: 41. 1878.

P. affinis (Müll.Arg.) Miers, Apocyn. S. Amer.: 40. 1878.

P. australis (Müll.Arg.) Miers, Apocyn. S. Amer.: 46. 1878.

P. hilariana (Müll.Arg.) Miers, Apocyn. S. Amer.: 41. 1878.

Nome vulgar: leiteira

Arbusto a arvoreta, $1-7 \mathrm{~m}$ alt.; caule rugoso. Folhas opostas, congestas no ápice dos ramos; oblongo-elípticas, ápice agudo e base aguda, 5,812.5x 1,6-2,8cm; membranáceas; concolores; glabras; venação camptódroma; pecíolo $2-7 \mathrm{~mm}$ compr. ; coléteres na região nodal. Inflorescência axilar, tirso congesto, multiflora; brácteas lanceoladas. Flores alvas, 0,8-1,1 cm compr.; lacínios do cálice lanceolados, com coléteres distribuídos uniformemente na base da parte interna; corola hipocrateriforme; tubo cilíndrico, inflado na base e contraído na região de inserção dos estames; lobos dolabriformes; estames inseridos no terço superior do tubo; anteras livres, ápice agudo e base sagitada; ovário glabro; cabeça do estilete cilíndrica, com projeções laterais no ápice e na base e dois apêndices apicais. Folículos divergentes, reniformes, muricados, esverdeados a castanhos na parte externa, avermelhados na parte interna, 2,2-3x1,5cm; sementes arredondadas, nigrescentes, envoltas por arilo vermelho intenso.

T. catharinensis ocorre no sudeste e sul do Brasil, Paraguai, Argentina e Uruguai. No Estado de São Paulo é amplamente distribuída e se popularizou como "praga de pastagens". Aparece em todos os ambientes estudados, exceto os de brejo. Flores de setembro a dezembro, frutos de janeiro a maio.

As espécies de Peschiera foram incluídas em Tabernaemontana por Leeuwenberg (1994b), na seção Peschiera. Tabernaemontana catharinensis tem sido identificada como Peschiera fuchsiaefolia Miers, espécie sinonimizada por Allorge (1983) a P. hystrix (Steud.) A.DC. (hoje T. hystrix Steud.) e que deve possuir os lobos da corola menores que o tubo, o que não está representado na maioria dos materiais dos herbários. Desta forma, Tabernaemontana catharinensis e T. hystrix têm sido frequientemente confundidas e identificadas de forma incorreta, levando-se em consideração os trabalhos de Allorge (1983) e Leeuwenberg (1994b).

Material examinado: BRASIL. São Paulo: Agudos, X/1992, fl., Silveira 1044 (BAUR); Bauru, X/1992, fl., Koch 57 \& Jesus (UEC); Bauru, X/1992, fl., Koch et al. 68 (UEC); Bauru, IV/1994, fr., Koch 188 \& Guimarães (UEC).

\section{Subfamília Apocynoideae}

Prefloração dextrorsa, anteras parcialmente férteis e adnatas à cabeça do estilete; sementes comosas. Está representada na região pelos gêneros: Forsteronia, Macrosiphonia, Mandevilla, Mesechites, Odontadenia, Peltastes, Prestonia. Rhodocalyx, Secondatia e Temnadenia.

\section{Forsteronia G. Mey.}

Lianas; râmulos opostos. Folhas opostas, às vezes verticiladas; coléteres na base da nervura principal na face adaxial e na região de inserção do pecíolo ao caule. Inflorescência terminal, tipo dicásio agregado ou tirsiforme, multiflora. Flores rotáceas a subrotáceas, alvo-amareladas, peque- 


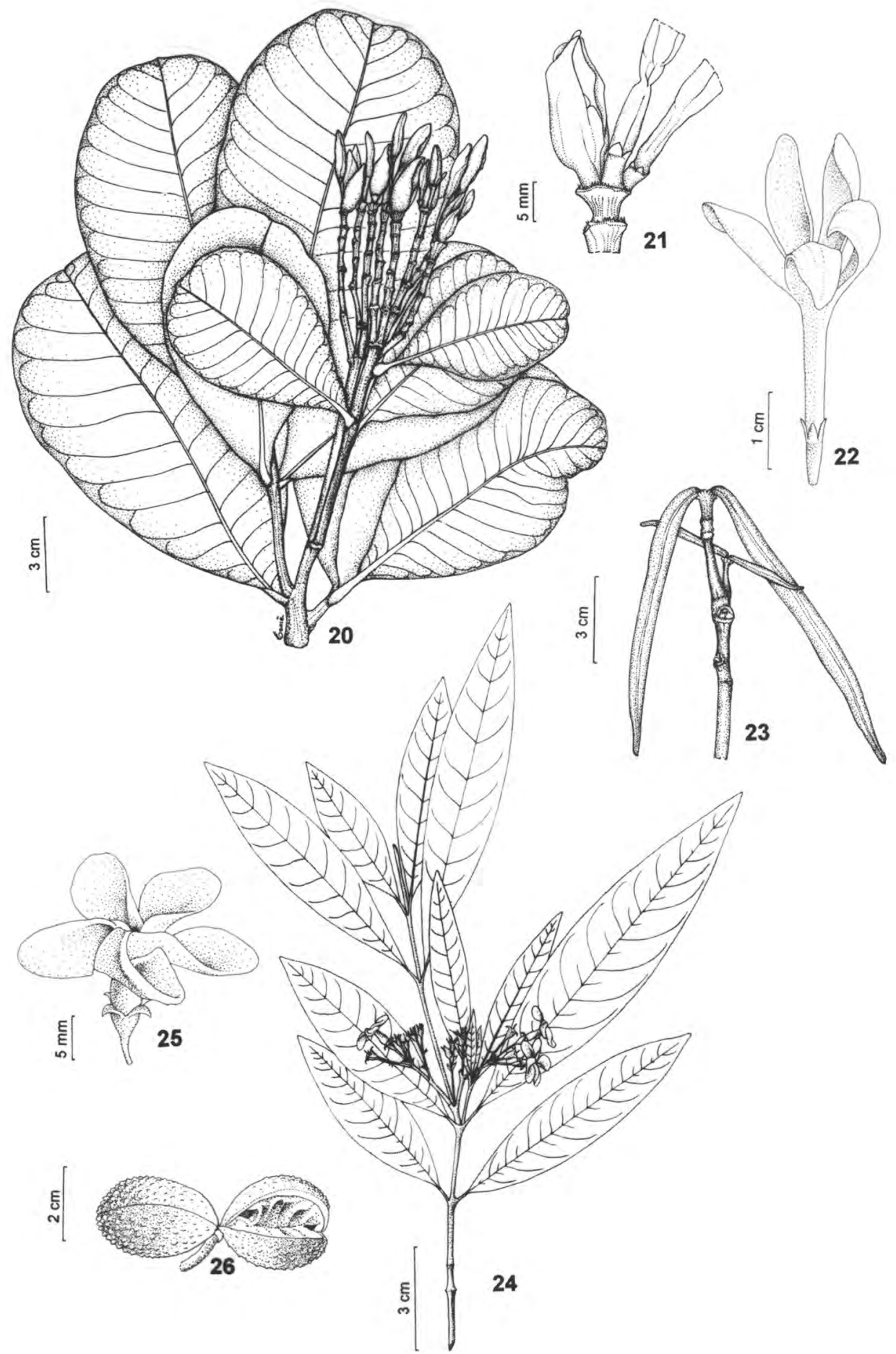

Figuras 20-23. Himatanthus obovatus (Müll. Arg.) Woodson: 20. ramo com flores; 21. parte da inflorescência; 22. flor (Koch 177); 23. fruto (Koch 113 \& Azevedo). Fig. 24-26. Tabernaemontana catharinensis A. DC.: 24. ramo com flores; 25 . flor (Koch 57 \& Jesus); 26. fruto (Koch 188 \& Guimarães). 
nas; cálice 5-partido, lacínios iguais, coléteres na face interna; corola com tubo cilíndrico; estames na porção mediana do tubo; anteras de ápice agudo, hialino e base sagitada, total ou parcialmente exsertas, filetes curvos, livres ou aderidos ao estilete; ovário apocárpico, circundado por 5 nectários separados ou concrescidos na base, de tamanho igual ou pouco mais curtos que o ovário; cabeça do estilete fusiforme, pentacostada, com dois apêndices no ápice. Folículos lenhosos, lineares, alongados, eretos ou pendentes, paralelos ou divergentes, moniliformes ou não; sementes comosas, castanho-avermelhadas.

Gênero neotropical com 46 espécies das quais cinco foram encontradas na região de estudo.

Bibliografia utilizada: Woodson (1935b); Hansen (1985).

Chave para identificação das espécies de Forsteronia

1. Folhas glabras, com domácias em criptas nas axilas das nervuras

2. Folhas 2,2-6,2x1,1-3,2cm; folículos moniliformes, parte mais larga $6-7 \times 2 \mathrm{~mm}$

6.1. F. glabrescens

2. Folhas $6,1-13,9 \times 3,2-4,9 \mathrm{~cm}$; folículos moniliformes, parte mais larga $1 \times 0,6 \mathrm{~cm}$

6.3. F. refracta

1. Folhas pilosas, domácias ausentes

3. Folhas com base obtusa ou subcordada, até $5,5 \mathrm{~cm}$ compr.; inflorescência subesférica ...

6.5. F. velloziana

3. Folhas com base aguda a obtusa, $5,5-16 \mathrm{~cm}$ compr.; inflorescência tirsiforme

4. Folículos paralelos, submoniliformes .....

6.2. F. pubescens

4. Folículos divergentes, não moniliformes

6.4. F. thyrsoidea

6.1. Forsteronia glabrescens Müll.Arg. in Mart., Fl. bras. 6(1): 102. 1878.

Fig. 27-29

Nome vulgar: cipó-de-leite

Ramos lenticelados, castanhos. Folhas elípticas a ovado-elípticas, ápice acuminado a cuspidado, base aguda, margem inteira, 2,2- 6,2×1,1-3,2cm; membranáceas a subcoriáceas; concolores; glabras, face abaxial com domácias em criptas nas axilas das nervuras; venação broquidódroma a camptódroma; pecíolo 3-5mm compr:; coléteres na nervura central da face adaxial da lâmina. Inflorescência tirsiforme, aproximadamente igual ou maior que as folhas subtendidas. Flores ca. $5 \mathrm{~mm}$ compr.; lacínios do cálice ovados; coléteres lineares, uniformemente distribuídos na face interna; corola pilosa internamente; lacínios linear-oblíquos; estames exsertos; ovário piloso na porção apical. Folículos pendentes, paralelos, glabros, moniliformes, $26-30 \mathrm{~cm}$ compr., partes mais largas $6-7 \times 2 \mathrm{~mm}$, distantes ca. $2,5 \mathrm{~cm}$.

Ocorre nas regiões sudeste e sul do Brasil, na Bolívia, no Paraguai, na Argentina e no Uruguai, em diversos tipos de vegetação. $\mathrm{Na}$ região foi observada em ambientes de mata estacional semidecídua e de cerrado. Flores de outubro a novembro e frutos de julho a dezembro.

Material examinado: BRASIL. São Paulo: Agudos, XII/1993, fr., Koch 171 \& Guimarães (UEC); Avaí, X/1992, fl,, Koch 64 et al. (UEC); Avaí, IX/1993, fr., Koch 136 \& Cavassan (UEC); Bauru, VI/1992, fr, Koch 44 et al. (UEC); Bauru, VII/1992, fr., Koch 28 \& Azevedo (UEC); Bauru, XI/1992, f1., Koch 76 \& Lazarin (UEC).

\subsection{Forsteronia pubescens A. DC. in}

DC., Prodr. 8: 436. 1844.

Fig. 30-32

Nome vulgar: cipó de leite

Ramos lenticelados. Folhas elípticas a ovado-elípticas, ápice cuspidado a caudado, base aguda, 5,4-14×2,7-5,6cm, membranáceas; concolores; indumento denso-piloso na face abaxial e esparso na face adaxial, tricomas simples; venação broquidódroma, mais evidente na face abaxial; pecíolo 4-8 mm compr. Inflorescência tirsiforme, densa, igual ou pouco maior que as folhas subtendidas. Flores ca. $6 \mathrm{~mm}$ compr.; lacínios do cálice lanceolados; coléteres numerosos opostos aos lacínios; corola pilosa internamente, lacínios lineares; estames exsertos; ovário piloso. Folículos pendentes, paralelos, submoniliformes, castanhoescuros, lenticelados, 15,3-30,2cm compr. 


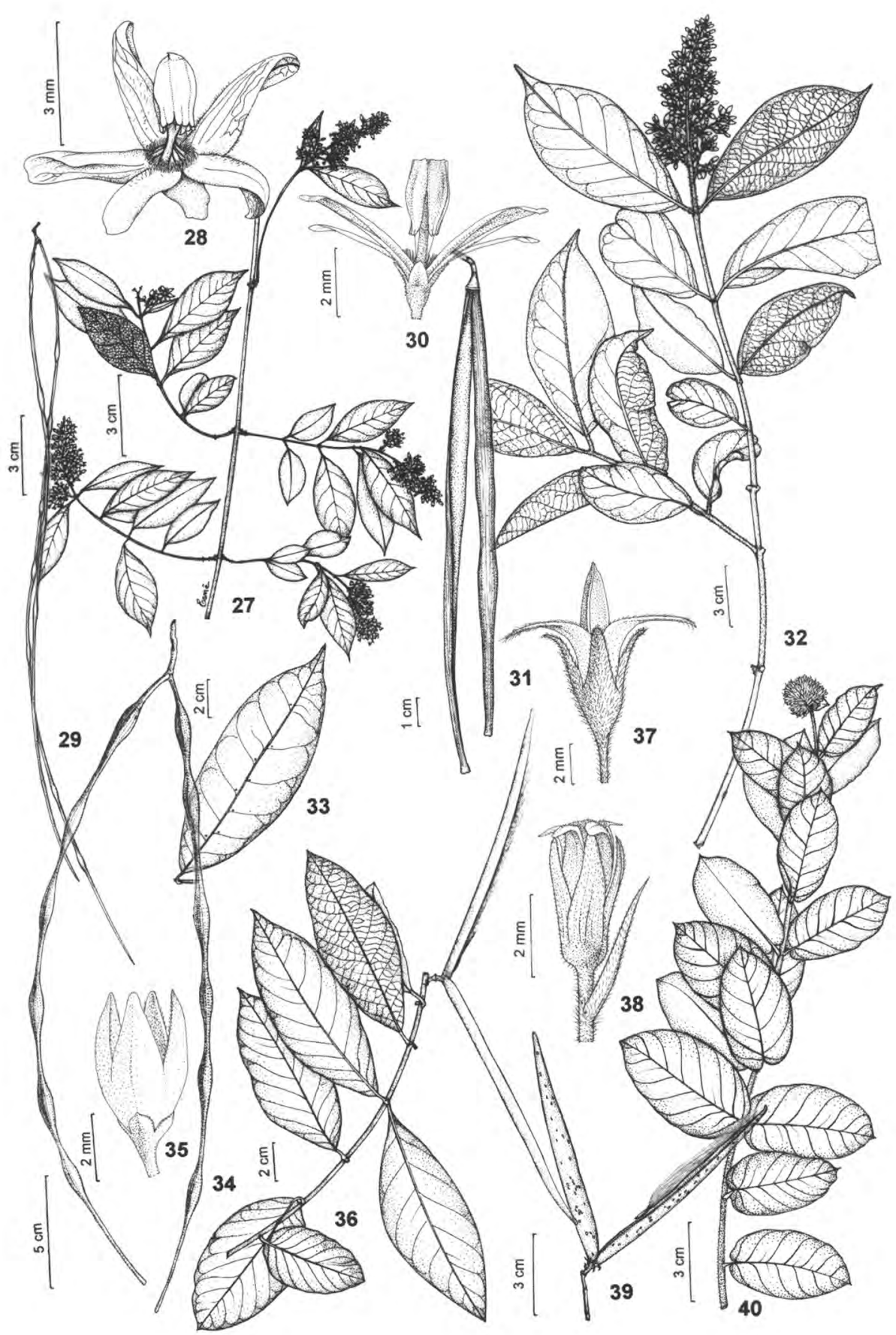

Figuras 27-29. Forsteronia glabrescens Müll. Arg.: 27. ramo com flores; 28. flor; 29. fruto (Koch 44 et al.). Fig. 30-32. Forsteronia pubescens A. DC.: 30. flor; 31.fruto; 32. ramo com flores (Koch 72 \& Azevedo). Fig. 33-35. Forsteronia refracta Müll.Arg.: 33, folha com domácias (Koch 176 \& Guimarães); 34. fruto (Hoehne s/n SPSF 017494) 35. flor (Gomes da Silva et al. 176). Fig. 36-37. Forsteronia thyrsoidea (Vell.) Müll.Arg.: 36. ramo com fruto (Koch 16 et al.); 37. flor (Gehrt s/n SP 4555). Fig. 38-40. Forsteronia velloziana (A. DC.) Woodson: 38. flor (Koch 159 \& Guimarães); 39. fruto ( Koch 131 et al.); 40. ramo com flores (Koch \& Azevedo $s / n$ UEC 052824). 
Ocorre no centro do Brasil, leste da Bolívia, norte do Paraguai e da Argentina. Encontrada em mata estacional semidecídua. Flores em outubro e novembro e frutos de maio a novembro.

Material examinado: BRASIL. São Paulo: Bauru, X/1992, fl., fr., Koch 66 et al. (UEC); Bauru, XI/1992, fr., Koch 72 \& Azevedo (UEC); Bauru, VI/1993, fr., Koch 120 \& Cavassan (UEC); Bauru, VI/1993, fr., Koch 121 \& Cavassan (UEC); Bauru, VIII/1993, fr., Koch 133 \& Jesus (UEC); Bauru, X/1993, fr., Koch 154 \& Jesus (UEC); Bauru, XI/1993, fr., Koch 169 \& Guimarães (UEC).

\subsection{Forsteronia refracta Müll.Arg. in}

Mart., Fl. bras. 6 (1): 97. 1860.

Fig. 33-35

Ramos castanhos, lenticelados, glabros. Folhas elípticas, oblongo-elípticas a oblanceoladas, ápice agudo a cuspidado, base aguda a levemente obtusa, 6,1-13,9x3,2-4,9cm; cartáceas; concolores; glabras, domácias em criptas nas axilas das nervuras da face abaxial; venação broquidódroma; pecíolo ca. $5 \mathrm{~mm}$ compr. Inflorescência tirsiforme, laxa. Flores ca. $4 \mathrm{~mm}$ compr.; lacínios do cálice oblongos, margem ciliada; coléteres uniformemente distribuídos na face interna; lacínios da corola ovais; estames com filetes apresentando uma protuberância dorsal abaixo da inserção das anteras; ovário piloso. Folículos pendentes, subparalelos, glabros, castanho-escuros, moniliformes, ca. $24 \mathrm{~cm}$ compr., partes mais largas ca. $1 \times 0,6 \mathrm{~cm}$, distantes $2,5-3,5 \mathrm{~cm}$.

Ocorre na Venezuela, Brasil, Paraguai e Argentina, sendo que no Brasil foi encontrada nos estados do Pará, Rio de Janeiro, Minas Gerais, São Paulo e Paraná. Na área estudada ocorre particularmente em regiões de mata estacional semidecídua. Flores em outubro e frutos principalmente em dezembro.

Esta espécie é bastante diferenciada das demais do gênero, principalmente por apresentar pequenos apêndices nos filetes. Tem sido pouco coletada no Estado de São Paulo.

Material examinado: BRASIL. São Paulo: Bauru, XII/1993, fr., Koch 176 \& Guimarães (UEC).
Material adicional examinado: BRASIL. Minas Gerais: Santana do Riacho, X/1981, fl. e fr., Furlan et al. s/n (UEC 36979). São Paulo: Iguape, XII/1990, f1., Gomes da Silva et al. 176 (UEC); Jales, IV/1950, fr., Hoehne $s / n$ (SPSF 017494).

\section{4. Forsteronia thyrsoidea (Vell.)}

Müll.Arg. in Mart., Fl. bras. 6 (1): 105. 1860.

Echites thyrsoidea Vell., Fl. Jlum. 3: 111. 1829.

Fig. 36-37

Caule castanho, lenticelado; ramos pilosos quando jovens, posteriormente glabros. Folhas elípticas a ovado-elípticas, ápice acuminado a cuspidado, base aguda a obtusa, 5,2-16,6×3$4,7 \mathrm{~cm}$; cartáceas; obscuramente discolores; indumento esparso-piloso na face adaxial e denso na face abaxial, principalmente ao longo das nervuras, tricomas simples; venação camptobroquidódroma; pecíolo 3-6mm compr. Inflorescência densamente tirsiforme, igual ou maior que as folhas subtendidas. Flores ca. $4 \mathrm{~mm}$ compr.; lacínios do cálice lanceolados a ovado-lanceolados, coléteres solitários alternos a estes, internamente; lacínios da corola oblongos; anteras parcialmente exsertas; ovário pubérulo. Folículos eretos, divergentes, glabros, castanho-claros, lenticelados, $14-15 \mathrm{~cm}$ compr.

Ocorre no centro do Brasil, Paraguai e Argentina. Neste trabalho, foi encontrada em ambientes de mata. Flores em novembro e frutos de abril a novembro.

Esta espécie é muito semelhante a $F$. pubescens quando em estado vegetativo. É, entretanto, facilmente reconhecida por seus folículos eretos e divergentes.

Material examinado: BRASIL. São Paulo: Avaí, IV/1992, fr., Koch 16 et al. (UEC); Bauru, XI/1992, fr., Koch 77 \& Azevedo (UEC).

Material adicional examinado: BRASIL. São Paulo: Ilha Queimada Grande, XI/1920, fl., Gehrt s/n (SP4555).

6.5. Forsteronia velloziana (A. DC.) Woodson, Ann. Missouri Bot. Gard. 21:622. 1934. Echites velloziana A. DC. in DC., Prodr. 8: 474.1844.

Fig. 38-40 
Ramos pilosos, castanho-acinzentados. Folhas oblongas a obovadas, ápice acuminado a cuspidado, base obtusa a subcordada, 2,3-5,5x 1,62,4cm; membranáceas; concolores; indumento piloso em ambas as faces, sendo mais denso na face abaxial, principalmente ao longo das nervuras, tricomas simples; venação camptódroma, mais evidente na face abaxial; pecíolo 2$4 \mathrm{~mm}$ compr. Inflorescência subesférica, mais curta que as folhas subtendidas, multiflora. Flores ca. 4mm compr.; lacínios do cálice linear-lanceolados; coléteres alternos aos lacínios; estames parcialmente exsertos; ovário curto piloso. Folículos lenhosos, eretos, divergentes, castanhos, lenticelados, 9-11 cm compr.

Espécie endêmica ao Brasil, de Minas Gerais a Santa Catarina. Na região de Bauru, foi encontrada apenas em ambiente de cerrado, preferencialmente aberto. Flores de setembro a novembro e frutos principalmente no mês de agosto.

Essa espécie é facilmente reconhecida por sua inflorescência subesférica e seus folículos pequenos.

Material examinado: BRASIL. São Paulo: Bauru, X/1990, fl., Koch \& Azevedo s/n (UEC 052824); Bauru, VIII/1993, fr., Koch 131 et al. (UEC); Bauru, X/1993, fl., Koch 159 \& Guimarães (UEC).

\section{Macrosiphonia Müll.Arg.}

Gênero com ca. de 10 espécies de distribuição anfitropical (Barban, 1985) ou cinco espécies sul americanas segundo Henrickson (1996), que elevou as espécies do subgênero norteamericano Telosiphonia, à categoria de gênero. Está representado na região por $M$. virescens.

Bibliografia utilizada: Woodson (1933); Barban (1985); Henrickson (1996).

\subsection{Macrosiphonia virescens (A.St.-Hil.)}

Müll.Arg. in Mart., Fl. bras. 6 (1): 139. 1860.

Echites virescens A. St. Hil. in Bull. Sci.

Soc. Philom. Paris: 77. 1824.

Fig. 41-43

Nomes vulgares: velame, velame-branco

Subarbusto ereto, ca. $50 \mathrm{~cm}$ alt., com xilopódio lenhoso; ramos pubescentes. Folhas opostas; sésseis a sub-sésseis; elípticas a ovadoelípticas, ápice acuminado, base obtusa a subcordada, 3,8-5,8x1,3-1,9cm; cartáceas; discolores; indumento alvo-lanoso na face abaxial e piloso na face adaxial, tricomas simples; venação camptódroma; coléteres na face superior do pecíolo. Inflorescência terminal, racemo com 1-3 flores; brácteas linear-lanceoladas. Flores alvas, ca. $9 \mathrm{~cm}$ compr., tubo amarelo na parte interna; lacínios do cálice verdes, linear-lanceolados, foliáceos; coléteres opostos aos lacínios, uniformemente distribuídos; corola infundibuliforme, albo-tomentosa; tubo cilíndrico com terço superior cônico-campanulado, 4 a 5 vezes maior que os lobos; lobos oblíquo-obovados, crispados; estames na base da parte cônica do tubo; filetes pilosos; anteras de ápice agudo e base truncada, aderidas a cabeça do estilete; ovário apocárpico, piloso; nectários unidos em disco irregular, menores que o ovário; estilete filiforme; cabeça do estilete umbraculiforme, com 2 pequenos apêndices apicais. Folículos lenhosos, eretos, paralelos, castanho avermelhados, submoniliformes; pilosos; 14-25cm compr.; sementes castanho-escuras.

Esta espécie é encontrada no Brasil, nas regiões centro-oeste, sudeste e sul, ocorrendo também no Paraguai e na Argentina. Nesta região ocorreu apenas em cerrado aberto. Flores de setembro a novembro e frutos em outubro e março.

Pode ser facilmente confundida $\operatorname{com} M$. longiflora pela aparência entretanto, apenas $M$. virescens possui o ovário piloso.

Material examinado: BRASIL. São Paulo: Agudos, IX/ 1993 fl., Koch 148 Bertoncini (UEC).

Material adicional examinado: BRASIL. Paraná: Monte Alegre, III/1957, fr., Kulmann s/ n (RB 150021). São Paulo: Pirassununga, XI/ 1994, fl., fr., Rachid s/n (SPF16549).

\section{Mandevilla Lindl.}

Subarbustos eretos, com xilopódio. Folhas opostas ou verticiladas, coléteres presentes na região nodal e na base da nervura principal da face abaxial da lâmina. Inflorescência terminal, racemo simples, com brácteas. Flores grandes, com mais de $5 \mathrm{~cm}$ compr.; cálice profundamente partido, coléteres na base da parte interna dos lacínios; 
corola infundibuliforme; estames inclusos, inseridos na base da parte alargada do tubo; filetes curtos, pilosos; anteras aderidas a cabeça do estilete, ápice hialino, agudo e base truncada; ovário apocárpico, com 2 nectários ovóides, menores que o ovário; estilete filiforme; cabeça do estilete umbraculiforme com dois apêndices apicais. Folículos delgados, eretos, subparalelos, submoniliformes; sementes rostradas.

O gênero possui ca. 100 espécies neotropicais, com ampla variação morfológica. Na região estudada foram encontradas três espécies.

Bibliografia utilizada: Woodson (1933); Sales (1993).

Chave para identificação das espécies de Mandevilla

1. Folhas lineares, com até $1 \mathrm{~cm}$ larg.

8.3. M. widgrenii

1. Folhas elípticas, oblongo-elípticas a suborbiculares, com mais de $1 \mathrm{~cm}$ larg.

2. Tubo da corola cilíndrico, metade superior cônica; menor ou igual aos lobos

8.1. M. illustris

2. Tubo da corola cilíndrico, mais estreito no terço inferior, duas vezes maior que os lobos

8.2. M. pohliana

8.1. Mandevilla illustris (Vell.) Woodson, Ann. Missouri Bot. Gard. 20:727. 1933.

Echites illustris Vell., Fl. Jlum. 3: 144. 1829.

Fig. 44

Subarbusto ca. $40 \mathrm{~cm}$ alt. Folhas opostas, oblongo-elípticas, orbiculares a obovadas, ápice arredondado, apiculado, base obtusa, subcordada, 4,6-7,8-11 ×3,7-4,9-9,5cm; cartáceas; concolores; indumento velutino em ambas as faces, tricomas simples; venação broquidódroma; pecíolo 1,8-6,7mm compr. Inflorescência 1-4(-10) flores; pedúnculo piloso, ca. $2 \mathrm{~cm}$ compr.; brácteas delicadas, lanceoladas. Flores rosa intenso, ca. $6 \mathrm{~cm}$ compr.; lacínios do cálice castanho-avermelhados, lanceolados, pilosos na face externa; coléteres opostos aos lacínios, dentiformes, uniformemente distribuídos; tubo da corola cilíndrico, metade superior cônica, menor ou igual aos lobos; lobos oblíquo-obovados, acuminados. Folículos lenhosos, avermelhados quando jovens e acinzentados quando maduros, $22-30 \mathrm{~cm}$ compr.

Ocorre no Sudeste do Brasil e no Paraguai, tendo sido observada em ambientes de cerrado aberto. Flores em outubro e novembro, frutos em outubro.

Material examinado: BRASIL. São Paulo: Agudos, XI/1994, fl., Bertoncini \&. Paschoal 474 (UNBA).

Material adicional examinado: BRASIL. Minas Gerais: Poços de Caldas, X/1980, fl, fr., Gabrieli et al. 306 (UEC). São Paulo: Cássia dos Coqueiros, XI/1994, fl., Kinoshita \& Silva 94.217 (UEC); Estreito, XI/1997, fl., Marcondes Ferreira et al. 1446 (UEC); Mogi Mirim, X/1983, fl., Nucci \& Rodrigues 15.473 (UEC); Santo Antônio da Posse, XI/1977, f1., I. Sazima \& M. Sazima 6.111 (UEC).

\subsection{Mandevilla pohliana (Stadelm.)}

Gentry, Ann. Missouri Bot. Gard. 71 (4): 1079. 1984. Echites pohliana Stadelm. in Flora 24(1): 73. 1841 .

Mandevilla velutina (Mart. ex Stadelm.) Woodson, Ann. Missouri Bot. Gard. 20: 731.1933.

Fig. 45-46

Subarbusto $30-60 \mathrm{~cm}$ alt. Folhas opostas, subsésseis; elípticas a oblanceoladas, ápice agudo a acuminado, base arredondada a subcordada, 6,511 x 1,2-2,3cm; cartáceas; concolores; glabras; venação broquidódroma. Inflorescência duas vezes mais longa que as folhas subtendidas, 2-9 flores; brácteas lanceoladas a ovado-lanceoladas. Flores róseas, $6-9 \mathrm{~cm}$ compr.; lacínios do cálice linear-lanceolados, glabros; coléteres alternos aos lacínios, em grupos de 4 ou 6; tubo da corola cilíndrico, mais estreito no terço inferior, 2 vezes maior que os lobos; lobos oblíquo-obovados, pouco acuminados. Folículos imaturos delgados, avermelhados, ca. $15 \mathrm{~cm}$ compr.

Ocorre em planaltos e montanhas das regiões centro-oeste, sudeste e sul do Brasil, estendendose para o oeste até a Bolívia e Paraguai, e para o sul, na Argentina. Na região estudada os indivíduos foram coletados somente em ambientes de cerrado aberto. Flores de outubro a janeiro e início de frutificação em fevereiro. 


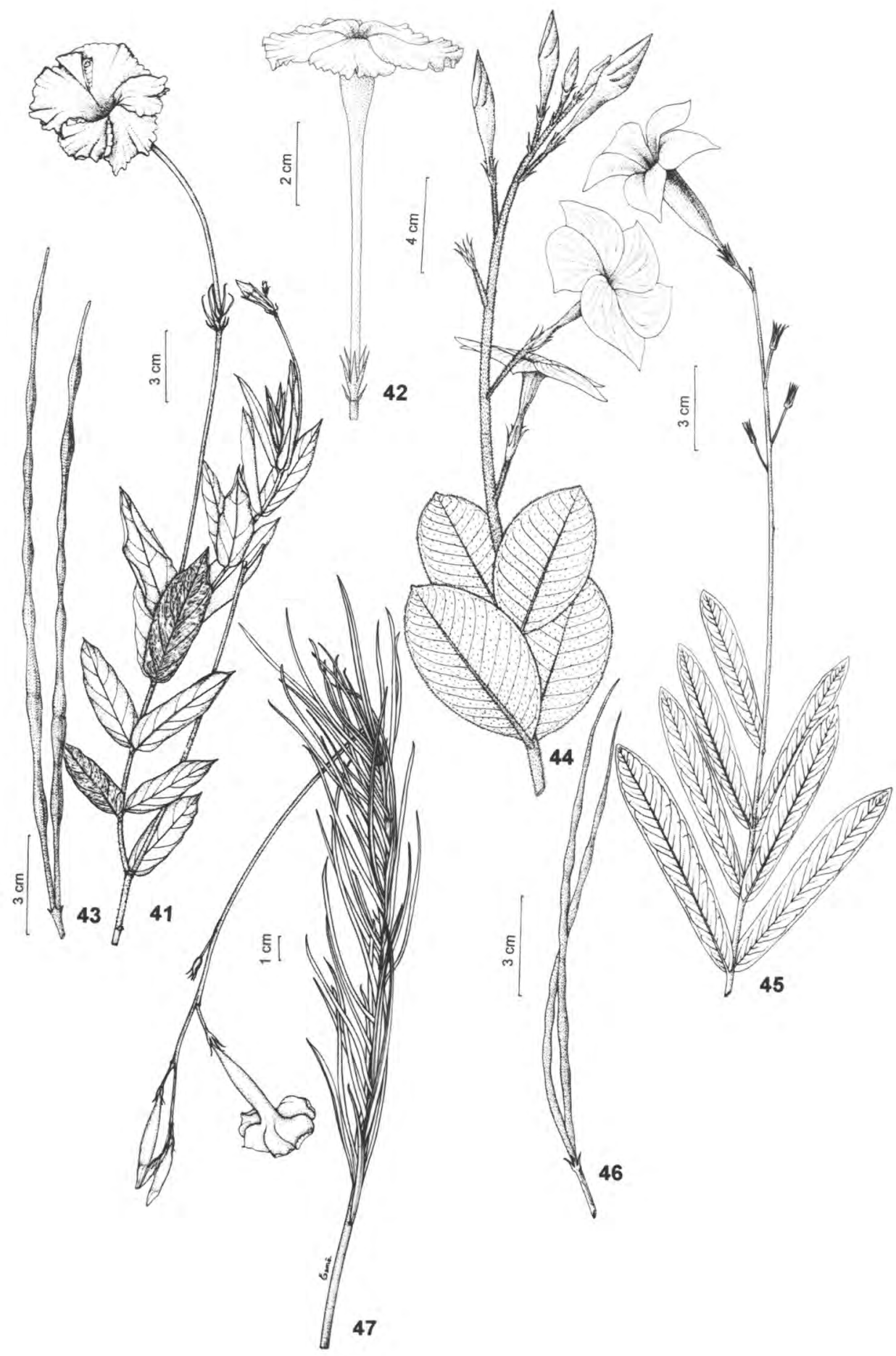

Figuras 41-43. Macrosiphonia virescens (A.St.-Hil.) Müll..Arg.: 41. ramo com flores; 42. flor (Koch 148 \& Bertoncini); 43 . fruto (Rachid s/n SPF 16549). Fig. 44. Mandevilla illustris (Vell.) Woodson: ramo com flores (Ferreira et al. 1446). Fig. 45-46. Mandevilla pohliana (Stadelm.) Gentry: 45. ramo com flores (Koch 174 \& Guimarães); 46. fruto (Leitão Filho et al. 20.654). Fig. 47. Mandevilla widgrenii Ezcurra: ramo com flores (Cavassan s/n UEC 30.785). 
Material examinado: BRASIL. São Paulo: Agudos, XI/1993, fl., Koch 161 et al. (UEC); Agudos, XII/1993, fl., Koch 173 \& Guimarães (UEC); Agudos, XII/1993, fl., Koch 174 \& Guimarães (UEC).

Material adicional examinado: BRASIL. São Paulo: Assis, II/1988, fr., Leitão Filho et al. 20.654 (UEC).

\subsection{Mandevilla widgrenii Ezcurra in} Spichiger \& Ramella, Candollea 45: 39. 1990.

Mandevilla linearis (Müll. Arg.) Woodson, Ann. Missouri Bot. Gard. 20: 733.1933.

Fig. 47

Subarbusto de 1,5-2m de alt., caule rugoso, avermelhado, lenhoso. Folhas opostas a verticiladas, sésseis a subsésseis; lineares, ápice agudo e base atenuada, 6,5-14,8 $00,2-1 \mathrm{~cm}$; cartáceas; concolores; glabras; venação hifódroma. Inflorescência terminal, racemo simples, $2-5$ flores; brácteas ovado-lanceoladas. Flores róseas, $6-10 \mathrm{~cm}$ compr.; lacínios do cálice lanceolados, verdes a avermelhados, glabros; coléteres dentiformes alternos aos lacínios; tubo da corola cilíndrico, mais estreito no terço inferior, 2 a 3 vezes maior que os lobos; lobos oblíquo obovados, pouco acuminados. Folículos maduros, avermelhados, $13-16 \mathrm{~cm}$ compr.

Ocorre no Brasil, nas regiões centro-oeste. sudeste e sul e no Paraguai. É de ambiente de cerrado, preferencialmente brejoso. Foram observadas flores nos meses de dezembro a fevereiro e frutos em julho. Tem sido pouco coletada no estado de São Paulo.

Material examinado: BRASIL. São Paulo: Agudos, I/1993 f1., Cavassan s/n (UEC 30785); Agudos, VII/1993 fr., Cavassan \& Koch 130 (UEC); Agudos, XII/1993 fl., Guimarães \& Koch 175 (UEC).

\section{Mesechites Müll.Arg.}

O gênero possui ca. de 10 espécies de distribuição neotropical.

Bibliografia utilizada: Woodson (1933).

9.1. Mesechites mansoana (A.DC.) Woodson. Ann. Missouri Bot. Gard. 20: 636. 1933.

Echites mansona A.DC. in DC., Prodr. 8: 448. 1844.
Fig. 48-50

Liana; ramos cilíndricos, castanho-avermelhados. Folhas opostas; elípticas a ovadoelípticas, ápice agudo a acuminado, base levemente arredondada a obtusa, espessa, 5,410,5 $\times 2,1-7,4 \mathrm{~cm}$; coriáceas; discolores; glabras; venação campto-broquidódroma; pecíolo 1-2,4cm compr.; coléteres escamiformes na base da venação principal na face adaxial e entre os pecíolos. Inflorescência axilar e terminal, cimosa, subcorimbosa, 12-32 flores; brácteas ovadas. Flores alvo-esverdeadas, $2-3 \mathrm{~cm}$ compr.; lacínios do cálice ovais, glabros; coléteres escamiformes alternos ou uniformemente distribuídos na face interna dos lacínios; corola hipocrateriforme, tubo estreitando-se na região de inserção dos estames; lobos oblíquo-ovóides; estames na porção médiosuperior do tubo; filetes pilosos; anteras de ápice agudo, hialino, base truncada, aderidas a cabeça do estilete; ovário apocárpico, glabro; 5 nectários de tamanho igual ou pouco maiores que ovário; estilete filiforme; cabeça do estilete cilíndrica com base anelar e 2 apêndices apicais. Folículos delgados, falcados, pendentes, castanho-claros, 11,5-25,5cm de comp; sementes castanhas.

Esta espécie ocorre no sudeste do Brasil, oeste da Bolívia e no Paraguai. Na região, foi observada tanto em ambientes de mata como de cerrado, preferencialmente em locais abertos. Flores de outubro a março e frutos de março a setembro.

As folhas desta planta chamam a atenção por apresentarem a coloração avermelhada quando expostas ao sol, e também pela margem de coloração mais tênue que a lâmina. Os coléteres escamiformes também são bastante característicos.

Material examinado: BRASIL. São Paulo: Avaí, VIII/1992, veg., Koch 53 \& Cavassan (UEC); Avaí, III/1993 fl., Cavassan \& Koch 99 (UEC); Avaí, III/1993, fl.,fr., Koch 100 \& Cavassan (UEC); Avaí, IX/1993, fr., Koch 135 \& Cavassan (UEC).

\section{Odontadenia Benth.}

Gênero neotropical com ca. 20 espécies. Bibliografia utilizada: Woodson (1935b). 
10.1. Odontadenia lutea (Vell.) Markgr., Feddes Repert. Spec. Nov. Regni Veg. Beih. 20: 24. 1924.

Echites lutea Vell., Fl. Jlum. 3: 109. 1829. Fig. 51-52

Liana; ramos robustos, lenticelados. Folhas opostas; elípticas a oblongo-elípticas, ápice agudo a cuspidado, base obtusa a subcordada, 915,2×2,5-5,9cm; membranáceas a coriáceas; concolores; glabras a pilosas, tricomas simples; venação camptódroma; pecíolo 3-9mm compr. ; coléteres na região nodal; estípulas interpeciolares lanceoladas, pilosas, caducas. Inflorescência axilar, tirsiforme, multiflora; brácteas triangulares, foliáceas. Flores alvas com interior do tubo amarelo, 4,5-6cm compr.; lacínios do cálice ovais, desiguais, margem ciliada; coléteres alternos aos lacínios; corola infundibuliforme; tubo cilíndrico, metade superior cônico-campanulada, inflado na base e contraído na região de inserção dos estames, $\mathrm{com}$ pilosidade em faixas abaixo dos filetes; lobos oblíquo-obovados; estames na base da parte cônica do tubo; anteras aderidas a cabeça do estilete, ápice agudo e base sagitada, curto-pilosas na parte dorsal e também na face ventral junto ao conectivo; ovário apocárpico, glabro; disco anelar 5-partido, maior que o ovário; cabeça do estilete fusiforme, 5 lobos basais tênues e 2 apêndices apicais. Folículos lenhosos, eretos, divergentes, ápices curvos, castanho-escuros, 9,8-15,5cm compr.; sementes rostradas.

Esta espécie ocorre no Brasil nos Estados do Pará, Rio de Janeiro, Minas Gerais, São Paulo e Mato Grosso, em ambientes de campo e cerrados. Foram observados indivíduos com botões florais a partir de novembro, tendo o máximo de floração de janeiro a abril. Frutos de abril a setembro.

Esta espécie é amplamente polimórfica, principalmente no que diz respeito às dimensões e ao indumento das folhas.

Material examinado: BRASIL. São Paulo: Agudos, IX/1993, fr, Koch 147 \& Bertoncini (UEC); Agudos, III/1994, fl., Koch 181 \& Bertoncini (UEC); Bauru, I/1992, fl., Koch 4 \& Azevedo (UEC); Bauru, IV/1992, f1., Koch 13 \& Azevedo (UNBA); Bauru, II/1994, fl., Koch 178 \& Azevedo (UEC).

\section{Peltastes Woodson}

Gênero com cinco espécies de distribuição neotropical.

Bibliografia utilizada: Woodson (1936).

11.1. Peltastes peltatus (Vell.) Woodson, Ann. Missouri Bot. Gard., 19: 376. 1932.

Echites peltata Vell., Fl. Flum. 3: 110. 1829.

Fig. 53-54

Liana, ramos lenticelados, indumento pubérulo ferrugíneo quando jovens, tornando-se glabros. Folhas opostas, peltadas; ovadas a arredondadas, ápice agudo a cuspidado, base obtusa a arredondada, 14,4-22,2x 11,3-14,6cm; cartáceas; concolores; glabras a pilosas, pubérulas em ambas as faces, tricomas simples; venação broquidódroma; pecíolo $4-7.5 \mathrm{~cm}$ compr. ; coléteres na região de inserção do pecíolo ao caule. Inflorescência axilar, 5-15 flores, dicásio reduzido, menor que as folhas subtendidas; brácteas obovadas, foliáceas. Flores amarelo-esverdeadas, $3-4,5 \mathrm{~cm}$ compr.; lacínios do cálice foliáceos, oblongos; coléteres opostos aos lacínios, na base da parte interna; corola infundibuliforme, tubo cilíndrico, inflado na base e contraído na região de inserção dos estames, metade superior cônico-campanulada; lobos oblíquodolabriformes; estames inseridos na base da porção alargada do tubo; anteras aderidas a cabeça do estilete, ápice agudo e base sagitada, curto-pilosas na porção dorsal; ovário apocárpico, puberulento a glabro; 5 nectários carnosos, iguais ou menores que o ovário; cabeça do estilete fusiforme, base anelar e 2 apêndices apicais. Folículos lenhosos, pendentes, paralelos, comumente unidos nas pontas, cilíndricos, glabros, castanho-escuros, ca. $14 \mathrm{~cm}$ compr.; sementes rostradas.

A espécie encontrada é endêmica ao Brasil, ocorrendo nos estados do Rio de Janeiro, Minas Gerais e São Paulo. Foi observada em mata estacional semidecídua e em ambientes encharcados. Flores de outubro a dezembro e frutos de julho a novembro.

Material examinado: BRASIL. São Paulo: Bauru, X/1991, f1., Koch 1 \& Cavassan (UEC); Bauru, VII/1993, fr., Koch 126 \& Azevedo (UEC); Bauru, VII/1993, fr., Koch 128 \& Azevedo (UEC); Bauru, XI/1993, fr., Koch 164 \& Azevedo (UEC). 


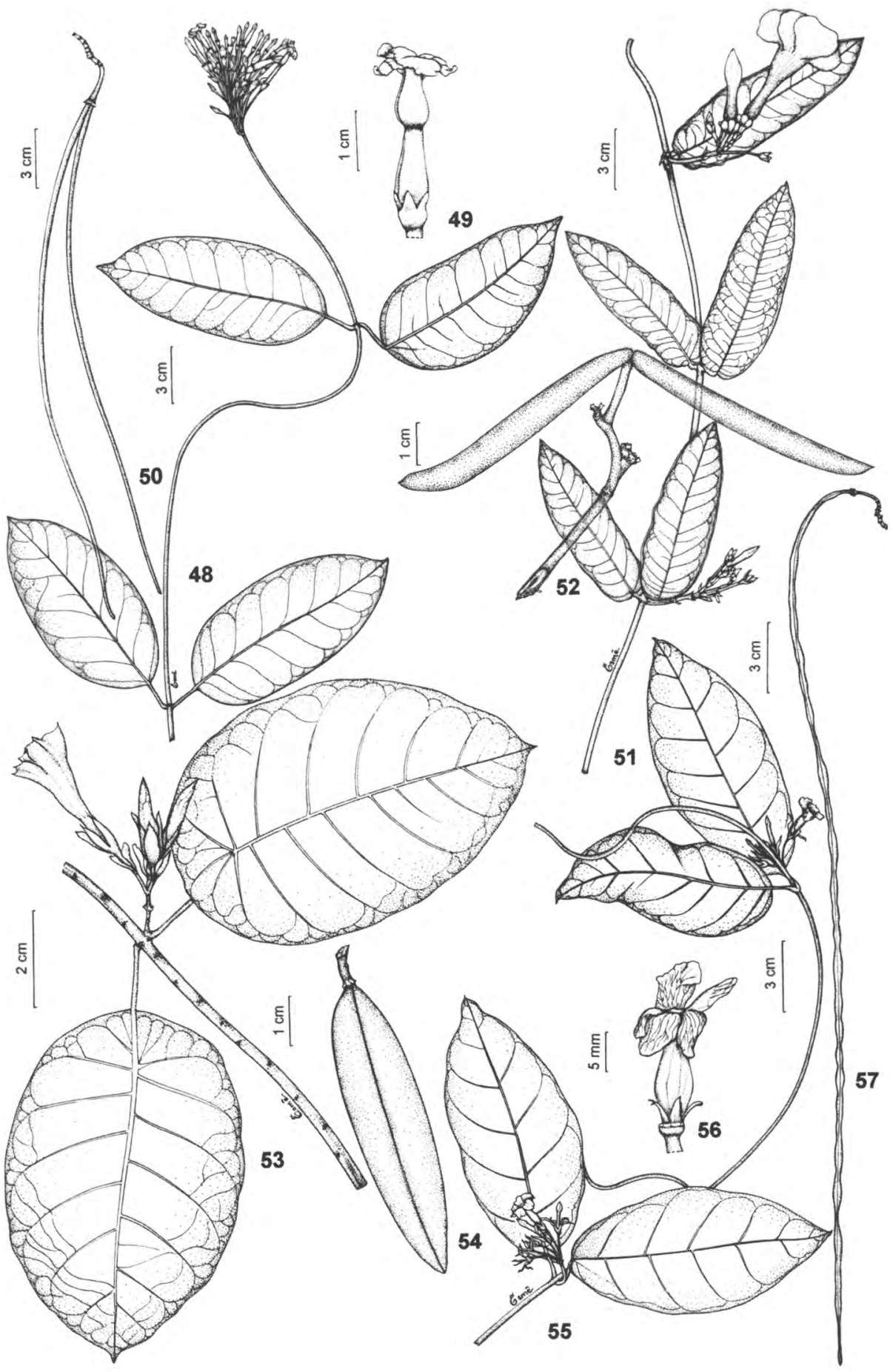

Figuras 48-50. Mesechites mansoana (A. DC.) Woodson: 48. ramo com flores; 49. flor (Koch 100 \& Cavassan ); 50 . fruto (Koch 135 \& Cavassan ). Fig. 51-52. Odontadenia lutea (Vell.) Markgr.: 51. ramo com flores; 52. fruto (Koch 4 \& Azevedo). Fig. 53-54. Peltastes peltatus (Vell.) Woodson: 53. ramo com flores (Koch 1 \& Cavassan ); 54. fruto (Koch 128 \& Azevedo). Fig. 55-57. Prestonia coalita (Vell.) Woodson: 55. ramo com flores; 56. flor (Koch 83 et al.); 57. fruto (Koch 45 \& Azevedo). 


\section{Prestonia $\mathrm{R}$. Br.}

Lianas. Folhas opostas, pecioladas, coléteres intrapeciolares na região nodal. Inflorescências laterais, cimosas, racemosas, às vezes corimbiformes, com brácteas. Flores amarelas; cálice com coléteres escamiformes deltóides na base da parte interna dos lacínios, opostos a estes; corola hipocrateriforme, fauce provida de anel caloso espesso ou tênue; estames na porção mediana do tubo, filetes pilosos, curtos e curvos; anteras aderidas a cabeça do estilete, ápice agudo e base sagitada; ovário apocárpico, circundado por 5 nectários; estilete filiforme; cabeça do estilete cilíndrica com anel basal e 2 apêndices apicais. Folículos delgados, pendentes, livres ou unidos até a maturidade, divergentes ou paralelos; sementes rostradas.

Gênero neotropical com ca. de 60 espécies. Bibliografia utilizada: Woodson (1936).

Chave para identificação das espécies de Prestonia

1. Folhas glabras a esparso-pilosas; inflorescência corimbiforme, congesta; anel da fauce tênue e inconspícuo

12.1. $P$. coalita

1. Folhas tomentosas; inflorescência racemosa, laxa; anel caloso evidente na fauce

12.2. P. riedelii

12.1. Prestonia coalita (Vell.) Woodson, Ann. Missouri Bot. Gard. 18: 552. 1931.

Echites coalita Vell., Fl. Flum. 3: 112. 1829.

Fig. 55-57

Ramos lenticelados, castanho-escuros, esparso-pilosos. Folhas elípticas a oblongoelípticas, ápice acuminado, base aguda a obtusa, 5-15×2-6cm; membranáceas; concolores, glabras a esparso-pilosas, tricomas simples; venação broquidódroma; pecíolos $0,5-1,8 \mathrm{~cm}$ compr. Inflorescência corimbiforme; brácteas lanceoladas, diminutas. Flores 1,4-2cm compr.; lacínios do cálice lanceolados a oblongo-lanceolados, acuminados, foliáceos ou subfoliáceos; tubo da corola inflado na base, contraído na região de inserção dos estames; anel tênue na fauce, inconspícuo; lobos assimétricos, oblíquo-obovados; anteras glabras; ovário glabro; nectários pouco mais curtos que o ovário. Folículos delgados, pendentes, paralelos, submoniliformes, unidos até a maturidade, glabros, $20-43 \mathrm{~cm}$ compr.; sementes castanhas.

Ocorre na Argentina, Paraguai e no Brasil, nos estados do Ceará, Bahia, Mato Grosso, Minas Gerais, Rio de Janeiro, São Paulo, Paraná e Rio Grande do Sul. Foi encontrada em cerrado e beira de matas, ocorrendo preferencialmente em ambientes abertos. Flores de dezembro a abril e frutos de março a junho.

Material examinado: BRASIL: São Paulo: Agudos, I/1993, fl., Koch 83 et al. (UEC); Agudos, III/1993, fr., Koch 96 et al. (UEC); Avaí, II/1992, fl., Koch 7 \& Cavassan (UEC); Avaí, IV/1992, fr., Koch 15 et al. (UEC); Bauru, IV/1992, fr., Koch 19 et al. (UEC); Bauru, VI/1992, fr., Koch 45 \& Azevedo (UEC); Bauru, VI/1993, fr., Koch 122 \& Cavassan (UEC); Bauru, III/1994, f1., Koch $179 \&$ Azevedo (UEC).

\subsection{Prestonia riedelii (Müll.Arg.)}

Markgr., Feddes Repert. Spec. Nov. Regni Veg. Beih. 20: 26. 1924.

Haemadictyon riedelii Müll. Arg. in Mart., Fl, bras. 6(1): 170, 1860.

Fig. 58-60

Ramos castanho-claros, denso-tomentosos a glabros. Folhas elípticas a ovado-elípticas, ápice acuminado, base aguda, 5-18×3-11; membranáceas; indumento tomentoso em ambas as faces, tricomas simples; concolores; venação broquidódroma; pecíolo 1,6-3,8cm compr. Inflorescência racemosa, laxa e alongada, 9-20 flores; brácteas foliáceas, oblongas a ovadolanceoladas. Flores amarelo-claras, ca. $1,5 \mathrm{~cm}$ compr.; lacínios do cálice foliáceos, lanceolados ou elíptico-lanceolados; corola com anel caloso evidente na fauce, tubo carnoso e espesso; lobos oblíquo-obovados; anteras pilosas na porção dorsal do ápice; ovário glabro; nectários compresso-ovóides, pouco mais curtos ou iguais ao ovário. Folículos delgados, pendentes, falcados, pilosos, unidos no ápice até a maturidade, $20-27 \mathrm{~cm}$ compr.

Ocorre desde o Peru e Bolívia até o Sul do Brasil, Paraguai e norte da Argentina. Foi 


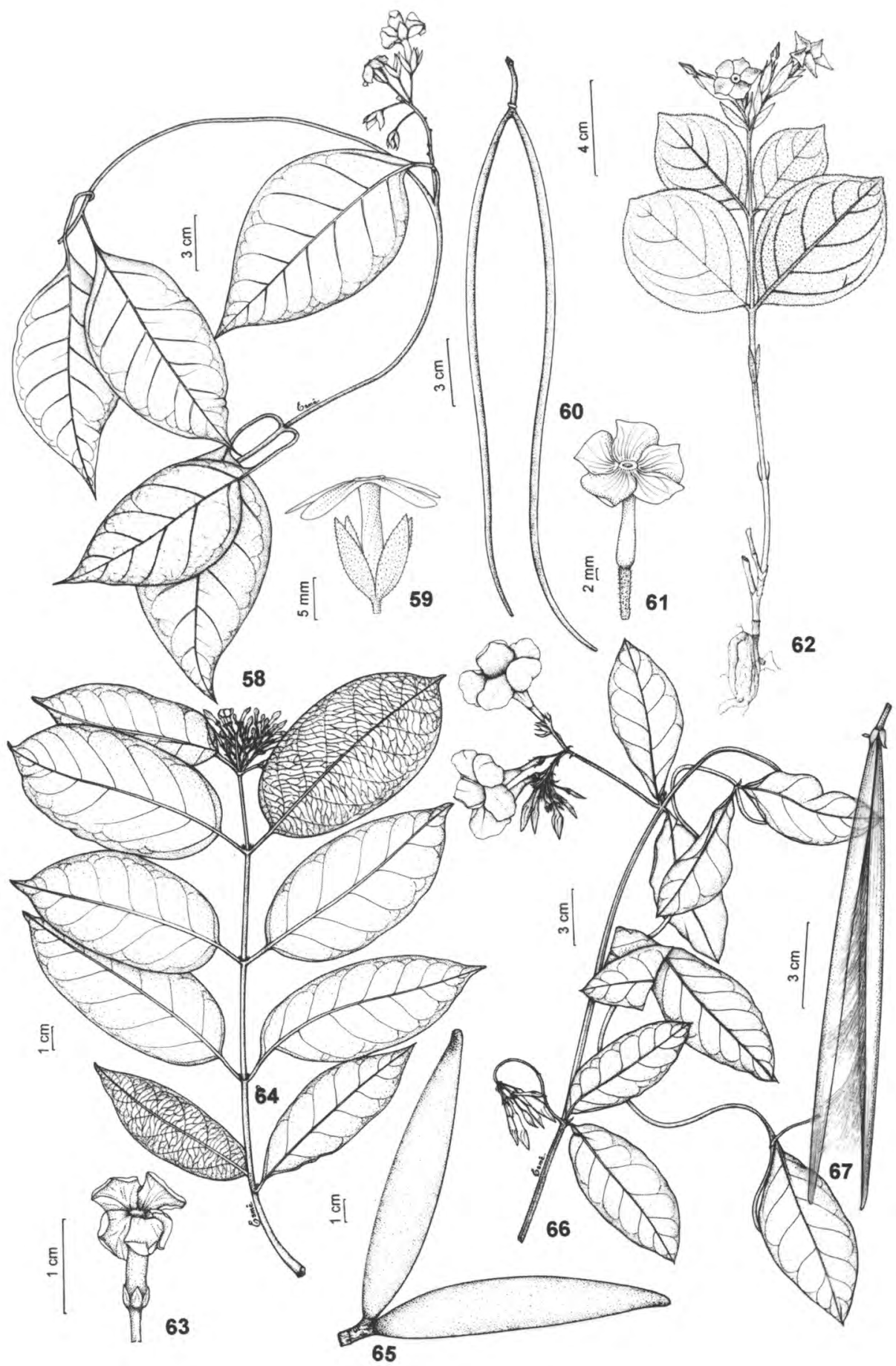

Figuras 58-60. Prestonia riedelii (Müll. Arg.) Markgr.: 58. ramo com flores; 59. flor (Koch 84 et al.); 60. fruto (Koch 97 et al.). Fig. 61-62. Rhodocalyx rotundifolius Müll. Arg.: 61. flor; 62. ramo com flores (Koch 162 \& Jesus). Fig.63-65. Secondatia densiflora A. DC.: 63. flor; 64. ramo com flores (Koch 158 \& Guimarães); 65. fruto (Koch 134 \& Cavassan ). Fig. 66-67. Temnadenia violacea (Vell.) Miers: 66. ramo com flores (Koch $3 \&$ Azevedo); 67. fruto (Koch 14 \& Azevedo). 
encontrada apenas em ambiente de mata, porém, em local bem iluminado. Flores de novembro a março e frutos de março a agosto.

Material examinado: BRASIL. São Paulo: Agudos, I/1993, fl., Koch 84 et al. (UEC); Agudos, III/1993, fr., Koch 97 et al. (UEC).

Material adicional examinado: BRASIL.

São Paulo: Cabreúva, III/1994, f1., Barreto et al. 2057 (UEC).

\section{Rhodocalyx Müll.Arg.}

Gênero monotípico que ocorre nas regiões norte, nordeste, centro-oeste e sudeste do Brasil e nordeste do Paraguai.

Bibliografia utilizada: Woodson (1936); Stranghetti \& Kinoshita (1996).

13.1. Rhodocalyx rotundifolius Müll.Arg. in Mart., Fl. bras. 6: 172. 1860.

Fig. 61-62

Subarbusto ereto, ca. $30 \mathrm{~cm}$ alt., xilopódio; ramos pubescentes. Folhas opostas, sésseis a subsésseis; ovadas a orbiculares; ápice arredondado a acuminado, base obtusa a arredondada, 5-9 $\times 3-$ $9 \mathrm{~cm}$; cartáceas; discolores; denso-pilosas em ambas as faces, indumento viloso mais denso nas nervuras da face abaxial, tricomas simples; venação broquidódroma; coléteres na região de inserção do pecíolo ao caule. Inflorescência terminal, cimosa, 7-12 flores, maiores que as folhas subtendidas; brácteas foliáceas a subpetalóides, ovado-oblongas, margem ciliada, vináceas. Flores de cor vinho com anel caloso amarelo, ca. $2 \mathrm{~cm}$; lacínios do cálice foliáceos a subpetalóides, vináceos, oblongo-elípticos, ápice acuminado, base cordiforme; coléteres opostos a cada lacínio; corola hipocrateriforme; lobos oblíquo-obovados; estames acima da porção mediana do tubo; filetes pilosos; anteras de ápice agudo, base sagitada, glabras; ovário apocárpico, ovóide, glabro; cabeça do estilete fusiforme, base anelada umbraculiforme e 2 apêndices apicais; 5 nectários mais curtos que o ovário. Folículos eretos, falcados, pubescentes, $17-19 \mathrm{~cm}$ compr. (Stranghetti \& Kinoshita 1996).

Foi encontrada apenas em cerrado aberto. Flores de outubro a fevereiro, frutos principalmente no mês de março.
Material examinado: BRASIL. São Paulo: Agudos, XI/1993, fl., Koch 162 \& Jesus (UEC); Bauru, XI/1996, fl., Cavassan 2045 (BAUR).

\section{Secondatia A. DC.}

Gênero neotropical com ca. sete espécies. Bibliografia utilizada: Woodson (1935b).

\subsection{Secondatia densiflora A. DC. in}

DC., Prodr. 8: 445. 1844.

Fig. 63-65

Liana robusta; caule rugoso; ramos opostos, lenticelados. Folhas opostas; elípticas, ovadas e oblongo-elípticas, ápice agudo a caudado, base obtusa a arredondada, $4-11 \times 2,5-5,6 \mathrm{~cm}$; membranáceas a coriáceas; concolores; glabras; venação campto-broquidódroma; pecíolo ca. $1 \mathrm{~cm}$ compr. ; coléteres dentiformes na região de inserção do pecíolo ao caule. Inflorescência terminal ou axilar; subcorimbosa; muitas flores; mais curtas que as folhas subtendidas; pedúnculo $0,4-1,3 \mathrm{~cm}$ compr.; brácteas ovadas a oblongo-ovadas, escariosas. Flores de cor creme, ca. 1,5cm compr.; lacínios do cálice ovais, margens ciliadas; coléteres alternos aos lacínios; corola hipocrateriforme; lobos da corola oblíquo-obovados, margem bulada; estames no quarto inferior do tubo; filetes pilosos; anteras aderidas a cabeça do estilete, com ápice agudo e base sagitada, pilosas dorsalmente; ovário apocárpico, ovóide, glabro; cabeça do estilete fusiforme, base alargada e 2 apêndices apicais; disco nectarífero 5-lobado, mais curto que o ovário. Folículos lenhosos, eretos, divergentes, cilíndricos, ápice agudo, castanho-escuros, 13$17 x \mathrm{ca} .2,5 \mathrm{~cm}$; sementes castanhas, rostradas, achatadas.

A espécie citada tem vasta distribuição extra amazônica na América do Sul. Neste trabalho foi encontrada em vários ambientes, sendo preferencialmente localizada em locais bem iluminados. Flores de setembro a novembro e frutos principalmente em setembro.

É liana bastante característica por ser muito robusta, chegando a possuir caule com $4-5 \mathrm{~cm}$ diâm. em indivíduos mais velhos e folhas de consistência coriácea e brilhante. Seus ramos opostos são também característicos, juntamente 
com os folículos que são mais robustos que na maioria das espécies coletadas.

Material examinado: BRASIL. São Paulo: Avaí, IX/1993, fl., fr., Koch 134 \& Cavassan (UEC); Avaí, X/1993, fl., fr., Koch 152 \& Cavassan (UEC); Bauru, IX/1992, fl., Koch 46 \& Guedes de Azevedo (UEC); Bauru, X/1993, fl., Koch 158 \& Guimarães (UEC).

\section{Temnadenia Miers}

Gênero sul-americano com quatro espécies, sendo três delas endêmicas ao Brasil.

Bibliografia utilizada: Woodson (1936); Santos (1996).

15.1. Temnadenia violacea (Vell.) Miers, Apocyn. S. Amer.: 208. 1878.

Echites violacea Vell., Fl. Flum. 3: 110. 1829.

Fig. 66-67

Liana; ramos castanhos, lenticelados, pilosos. Folhas opostas; elípticas a ovado-elípticas; ápice agudo, base aguda a obtusa; 4,7-10,2x1,9$5.5 \mathrm{~cm}$; membranáceas; discolores; venação broquidódroma, indumento velutino em ambas as faces, tricomas simples; pecíolo 2-5mm compr.; coléteres na região de inserção do pecíolo ao caule. Inflorescência cincino dicotômico, axilar, 9-14 flores, maior que as folhas subtendidas; brácteas lanceoladas, subfoliáceas, pilosas. Flores de coloração vinho intenso, ca. $4,8 \mathrm{~cm}$ compr.; lacínios do cálice lanceolados, pilosos, coléteres opostos aos lacínios, corola infundibuliforme; tubo cilíndrico, constrito na região de inserção dos estames, metade superior cônica, esverdeada; lobos oblíquo-obovados; estames na base do tubo superior; anteras aderidas a cabeça do estilete, de ápice agudo e base sagitada, pilosas na parte dorsal; ovário apocárpico, glabro; 5 nectários iguais ou pouco maiores que o ovário; cabeça do estilete cilíndrica com anel basal e 2 apêndices apicais. Folículos lenhosos, pendentes, paralelos, unidos até a maturidade, castanho-escuros, 15,7$27 \mathrm{~cm}$ compr.; sementes rostradas, castanhoavermelhadas.

Ocorre no Brasil nos Estados do Ceará, Minas Gerais, Rio de Janeiro, São Paulo e Paraná, preferencialmente em ambientes de cerrado e campo. Flores de julho a fevereiro e frutos de março a setembro.

Material examinado: BRASIL. São Paulo: Agudos, IX/1993, fl., fr., Koch 138 \& Jesus (UEC); Bauru, XII/1993, fl., Cavassan 2001 (BAUR); Bauru, X/1991, fl., Koch 2 \& Azevedo (UEC); Bauru, XI/1991, fl., Koch 3 \& Azevedo (UEC); Bauru, IV/1992, fr., Koch 14 \& Azevedo (UEC); Bauru, VII/1993, fr., Koch $129 \&$ Azevedo (UEC).

Como considerações finais, acrescenta-se que os meses em que ocorreram o maior número de espécies em fruto e flor foram julho e outubro, respectivamente. A maioria das espécies encontradas possui ampla distribuição geográfica, mas, algumas delas têm sido pouco coletadas no Estado de São Paulo, como Forsteronia refracta, F. thyrsoidea e Mandevilla widgrenii. Visto que várias espécies comuns e algumas espécies raras ou pouco coletadas foram encontradas em todos os ambientes analisados, considera-se que a família Apocynaceae está bem representada na região de Bauru, apesar desta ter sofrido grandes alterações em sua vegetação nos últimos anos.

Analisando a distribuição das espécies nos ambientes estudados, constata-se que grande parte delas ocorre em uma formação vegetal preferencial. Assim, tem-se Aspidosperma tomentosum e Rhodocalyx rotundifolius apenas em cerrado, e Aspidosperma cylindrocarpon e Condylocarpon isthmicum apenas em formações de mata. Algumas espécies foram encontradas tanto em formações de cerrado como de mata, como Forsteronia glabrescens. Outras foram observadas na maioria das formações visitadas como Tabernaemontana catharinensis e Prestonia coalita. Estas, só não foram encontradas em ambientes encharcados, sendo as espécies mais comuns na região. Em ambientes encharcados ocorreram Peltastes peltatus em mata, e Mandevilla widgrenii em cerrado.

Deve-se ressaltar a importância de trabalhos com floras locais para detectar a existência de espécies pouco coletadas, restritas a ambientes específicos que merecem ser preservados; para aumentar o número de registros e informações das espécies; para levantar a existência de problemas 
taxonômicos e para fornecer subsídios para estudos futuros.

\section{Agradecimentos}

As autoras agradecem a Prof. Dr. Osmar Cavassan pelo estímulo e auxílio em todas as fases do trabalho; ao Departamento de Ciências Biológicas da UNESP de Bauru, pela permissão do uso de suas instalações; aos diretores e administradores das Reservas e Parques visitados; a Adriana M. Guedes de Azevedo, Alzira P. Bertoncini, Ana Rosa S. Jesus e Paula C. Lazarin pelo auxílio durante o trabalho de campo; a Dr. Volker Bittrich, Ângela Sartori e Simone P. Teixeira pelas críticas e sugestões apresentadas; a Esmeralda Zanchetta Borghi e Eduardo Kickhöfel pelas ilustrações; à FAPESP pelo auxílio concedido; ao CNPq pelo suporte financeiro através de bolsa de Mestrado ao primeiro autor.

\section{Referências bibliográficas}

Allorge. L. 1980. Considerations sur la systematique des Apocynacées. In L. Allorge: H. P. Husson \& C. Sastre (ed.). Morphologie et chimiotaxonomie de Apocynacées: Conclusions phylogenetiques et biogéographiques. Compte rendu sommaire des séances de la societé de biogéographie 57(3): 112-126.

Allorge, L. 1983. Morphologie, systématique, chimiotaxonomie et biogéographie des Tabernamontanoidées (Apocynacées) Américanes. Thesis. Université de Paris-Sud, Paris.

Azambuja. D. de 1947. Contribuição ao conhecimento das Apocynaceae encontradas no Brasil. Arquivos do Serviço Florestal 3: 9-12.

Barban. J. R. 1985. Revisão taxonômica do gênero Macrosiphonia Müll. Arg. (Apocynaceae). Dissertação de Mestrado. UNICAMP, Campinas.

Barroso. G. M.: Guimarães, E. F.; Ichaso, C. L. F.; Costa, C. G.: Peixoto, A. L. \& Lima. H. C. 1986. Sistemática de angiospermas do Brasil: III. UFV. Imprensa Universitária, Viçosa.

Bragatto-Vasconcellos, M. \& Kinoshita-Gouvêa, L. S. 1993. As Apocynaceae de Poços de Caldas. Minas Gerais, Brasil. Acta Botanica Brasilica 7(1): 107-127.

Cavassan. O.: César, O. \& Martins, F.R. 1984. Fitossociologia da vegetação arbórea da Reserva Estadual de Bauru. estado de São Paulo. Revista Brasileira de Botânica $7(2): 91-106$

Cavassan. O. 1990. Florística e fitossociologia da vegetação Ienhosa de um hectare de cerrado do Parque Ecológico
Municipal de Bauru - SP. Tese de Doutorado UNICAMP. Campinas.

Coutinho. L. M. 1978. O conceito de cerrado. Revista Brasileira de Botanica 1: 17-23.

Cronquist. A. 1981. An Integrated Sistem of Classification of Flowering Plants. Columbia University Press. New York.

Fallen. M. 1983. A taxonomic revision of Condylocarpon (Apocynaceae). Annals of the Missouri Botanical Garden 70: 149-169.

Felippe. G. M. \& Alencastro, F. M. M. 1966. Contribuição ao estudo da nervação foliar das compositae dos cerrados. I - Tribos Helenieae, Helianthae, Inulae. Mutisiae e Senecionae. Anais da Academia Brasileira de Ciências 38: $125-157$.

Ferracini. M. C.: Ferlini, R. F. \& Cavassan, O. 1983. Composição florística de uma área de cerrado no município de Bauru, SP. Salusvita 2: 01-09.

Hansen. B. 1985. A monographic revision of Forsteronia (Apocynaceae). Thesis. University of South Florida,

Henrickson. J. 1996. Studies in Macrosiphonia (Apocynaceae): generic recognition of Telosiphonia. Aliso 14(3): 179-195.

Holmgren, P. K.. Holmgren, N. H. \& Barnett, L. C. 1990. Part. I. The Herbaria of the World. 8 ed. New York Botanical Garden, New York.

Judd. W. S., Sanders, R. W., Donoghue, M. J. 1994. Angiosperm family pairs: preliminary phylogenetic analyses. Harvard Papers in Botany 5: 1-51.

Kinoshita-Gouvèa, L. S. \& Baldassari, I. B. 1987. Flora Fanerogâmica do Parque Estadual das Fontes do Ipiranga (São Paulo. Brasil). Apocynaceae. Hoehnea 14: 89-94.

Kronki, F. J. N.: Matsukuma, C. K.; Nalon, M. A.; Del Cali, I. H.: Rossi. M.; Mattos, I. F. A.; Shin-Ike, M. S.: Pontinhas. A. A. S. 1993. Inventário florestal do Estado de São Paulo. Instituto Florestal, São Paulo.

Lawrence. G. H. 1951. Taxonomy of vascular plants. MacMillan. New York.

Leeuwenberg. A. J. M. 1994a.Taxa of the Apocynaceae above the genus level. Series of Apocynaceae, XXXVIII. Wageningen Agricultural Univiversity Papers 94-3: 47-60.

Leeuwenherg. A. J. M. 1994b. A revision of Tabemaemontana two. The new world species and Stemnadenia. Series of revisions of Apocynaceae: XXXVI. Royal Botanic Gardens, Kew.

Marcondes-Ferreira. W. 1988. Aspidosperma Mart., nom. cons. (A pocynaceae): estudos taxonômicos. Tese de Doutorado. UNICAMP, Campinas.

Marcondes-Ferreira, W. \& Kinoshita, L. S. 1996. Uma nova divisão infragenérica para Aspidosperma Mart. (Apocynaceae). Revista Brasileira de Botânica 19(2): 20.3-214.

Markgraf. F. 1968. Apocynaceae. In R. Reitz (ed.), Flora Ilustrada Catarinense. Itajaí.

Miers. J. 1878. Apocynaceae of South America. Williams \& Morgate. London.

Monachino. 1945. A revision of Hancornia (Apocynaceae). Lilloa 11: 19-48. 
Müller. J. 1860. Apocynaceae. In C. P. P. Martius \& A. G. Eichler (ed.). Flora Brasiliensis. Lipsiae, Frid. Fleisher. v. 6 pt.1.

Plumel. M. M. 1991. Le genre Himatanthus (Apocynaceae) révision taxonomique. Bradea 5: (suplemento).

Radford, A. E.; Dickson, W. C.; Massey, J. R. \& Bell, C. R. 1974. Vascular Plant systematics. Harper \& Row, Publishers. New York.

Rizzini. C. T. \& Mors, W. B. 1976. Botânica Econômica Brasileira. EPU e USP, São Paulo.

Sales. M. F. de 1993. Estudos taxonômicos de Mandevilla Lindley subgênero Mandevilla (A pocynaceae) no Brasil. Tese de Doutorado. UNICAMP. Campinas.

Santos. L. B. 1996. Estudos morfológicos e taxinômicos do gênero Temnadenia Miers (Apocynaceae). Dissertação de Mestrado. UFRJ, Rio de Janeiro.

Sennblad. B. \& Bremer, B. 1996. The familial and subfamilial relationships of Apocynaceae evaluated with rbcL data. Plant Systematics and Evolution 202: 153-175.

Stranghetti. V. \& Kinoshita, L. S. 1996. Reavaliação do gênero monotípico Rhodocalyx Müll.Arg. (Apocynaceae). Revista Brasileira de Botânica 19(2): 133-144.

Struwe. L.. Albert, V. A. \& Bremer, B. 1994. Cladistics and family level classification of Gentianales. Cladistics 10: 175-206.
Sugiyama, M. 1991. Apocynaceae. Pp. In M. M. R. F. Melo et al. (ed.). Flora Fanerogâmica da Ilha do Cardoso; caracterização geral da vegetação e listagem das espécies ocorrentes. Instituto de Botânica, V. 1. São Paulo.

Woodson, J. E. Jr. 1930. Studies in the Apocynaceae I. A Critical study of the Apocynoideae (with special reference to the genus Apocynum). Annals of the Missouri Botanical Garden 17: 1-212.

Woodson. J. E. Jr. 1933. Studies in the Apocynaceae IV The American Genera of Echitoideae. Annals of the Missouri Botanical Garden 20(1): 605-790.

Woodson. J. E. Jr. 1935a. Observations on the inflorescence of Apocynaceae. Annals of the Missouri Botanical Garden 22(1): 1-48.

Woodson. J. E. Jr. 1935b. Studies in the Apocynaceae IV The American Genera of Echitoideae. Annals of the Missouri Botanical Garden 22(2): 153-306.

Woodson, J. E. Jr. 1936. Studies in the Apocynaceae IV. The American Genera of Echitoideae. Annals of the Missouri Botanical Garden 23: 169-438.

Woodson. J. E. Jr. 1951. Studies in the Apocynaceae VIII. An interim revision of the genus Aspidosperma Mart. \& Zucc. Annals of the Missouri Botanical Garden 38: 119-204. 